\title{
Does Wage Justice Hamper Creativity? Pay Gap and Firm Innovation in
}

\section{China}

Abstract: Although the pay gap between executives and employees has received considerable attention, its economic consequences remain unclear due to the unavailability of data. In this study, we examine the effects of the pay gap on firm innovation by using data from Chinese listed firms. We show that: 1) the first-order effect of pay gap on firm innovation is significantly positive, supporting the tournament theory; 2) however, when pay gap is relatively high, the importance of comparison theories increases; 3) high management pay premiums provide incentives for management to devote to innovation activities, while pay premiums for ordinary employees impede firm innovation; and 4) both the employee's human capital and state ownership play significant roles in the negative effects of employee pay premiums on firm innovation. Overall, we provide critical insights and a serious challenge for regulators in China. The policy implications of this study could be of interest to regulators who intend to encourage firm innovation.

Key words: Pay gap; Innovation; Pay Premium; Human Capital; Ownership JEL classifications: O3; P2; G3

\section{Introduction}

The pay gap between executives and employees has received more and more attention recently. For example, on August 5, 2015, the Securities and Exchange Commission of the United States approved a rule as part of the Dodd-Frank Wall Street Reform and Consumer Protection Act, requiring publicly traded companies to disclose the pay gap between CEO and ordinary 
employees $^{1}$, which would provide a new weapon for organizations protesting against income disparity exacerbation and an extra reference for investors to decide whether to invest in a particular firm. However, opponents say that the rule would divert attention away from the underlying causes of income inequality and only focus on the pay ratio ${ }^{2}$. Likewise, the Chinese government has also issued policies limiting executive pay in state-owned enterprises (SOEs). Since January 1, 2015, a salary reform scheme for central enterprise principals has been implemented, targeting some 200 executives from 72 SOEs, and putting in place a ceiling for executive-worker pay ratio, which has been trimmed down to about eight times ${ }^{3}$.

Although an emerging literature takes up the task of trying to understand the economic effect of pay gaps within a top management team (Lee et al., 2008; Kale et al., 2009), between managers and ordinary employees (Faleye et al., 2013; Firth et al., 2015; Banker et al., 2016), and within ordinary employees from a firm (Lallemand et al., 2004), few empirical studies examine the link between intra-firm pay gaps (which denotes the pay dispersions between managers and ordinary employees) and firm innovation. In this paper, we try to contribute to this nascent literature by examining how intra-firm pay gaps affect innovation output.

Innovation is an important factor considered by both policy makers and firms. Innovation upgrades a firm's comparative advantage (Porter, 1992) and is a critical driver of economic growth (Solow, 1957). Nurturing innovation is of considerable importance to China because it has identified building an innovative country as a national development strategy. However,

${ }^{1}$ http://www.foxbusiness.com/politics/2015/08/05/sec-approves-ceoworker-pay-gap-rules.html http://www.ibtimes.com/sec-approves-pay-ratio-rule-created-under-dodd-frank-act-2040380?rel=latest3

2 http://www.wsj.com/articles/should-congress-rescind-the-pay-ratio-rule-1456715962

3 http://www.chinadaily.com.cn/business/2015-01/05/content 19235462.htm On September 16, 2009, a guideline to regulate the salaries for executives in the country's 135 centrally-administered state-owned enterprises was announced by six administrative departments of China's central government, stipulating that the executive pay shall not exceed 20 times the pay of the average worker. http://www.chinadaily.com.cn/china/2009-09/16/content_8700389.htm 
promoting innovation is a challenge for most firms (Tian and Wang, 2014). Belloc (2012) argues that the core component of firm innovation is the process through which individuals integrate their human capital and physical resources within the firm. Although shareholders' investments are thought to be the only fundamental source of productive activities, superior profit sharing provides incentives for employees (including the management group and ordinary employees) to devote their skills and efforts to the innovation process (Lazonick, 2003).

Prior studies show that a number of firm characteristics could affect managerial or employee incentives on participating in innovation activities. For instance, the innovation incentives of managers are motivated by a larger institutional ownership (Aghion et al., 2013), corporate venture capital (Chemmanur et al., 2014), private equity ownership (Lerner et al., 2011; Bernstein, 2015), greater tolerance for failure (Ederer and Manso, 2013; Tian and Wang, 2014), , lower analyst coverage (He and Tian, 2013) and higher promotion-based tournament prize for non-CEO executives (Jia et al., 2016). Meanwhile, employee incentive is also important in innovation activities, for example, non-executive employee stock options have a positive effect on firm innovation (Chang et al., 2015) while unionization impedes firm innovation (Bradley et al., 2016). Therefore, to maximize the utilization of both the management group and ordinary employees, firms need to establish proper incentive mechanisms to motivate them to engage in activities that promote innovation (Gupta et al., 2007). However, few empirical studies integrate both the managerial and employee incentives in innovation process.

In fact, both the management groups and ordinary employees play important roles in innovation activities. It is easy to understand the importance of managers since they are the decision-makers of R\&D investments in firms (Barker and Mueller, 2002), the separation of ownership and control of listed firms makes managerial incentive an issue for firms to mitigate 
managerial myopia and induce the management to engage in value-enhancing innovation activities (He and Tian, 2013). Meanwhile, rank-and-file employees are also not that inessential. Even the blue-collar workers, who seem to be less obviously associated with innovation activities at first blush, could have both direct and indirect effect on innovation, on one hand, many patentable ideas are initially generated by them since their advantages in closest contacts with production; on the other hand, they may affect innovation productivity since they often serve as supporting staff for scientists and engineers (Bradley et al, 2016).

For the above reasons, we conduct our research from the perspective of pay gap between management group and employees (which we will interchangeably refer to as intra-firm pay gap or firm pay gap). We argue that the firm pay gap can affect firm innovation by affecting the incentives of both managers and employees. In the literature, there are two competing theories that describe the economic incentives of pay gaps, the tournament theory and comparison theories.

The tournament theory was first formulated by Lazear and Rosen (1981) and subsequently extended by Rosen (1986), and proposes that firms motivate employees by setting up a hierarchy of compensation. Payment at a given level in the organizational hierarchy induces effort from employees at both its own level and the next lower hierarchical level (Rajgopal and Srinivasan, 2006). Consistent with the tournament theory, empirical evidence has found that the pay gap is positively associated with firm performance (Lallemand et al., 2004; Lee et al., 2008; Kale et al., 2009; Banker et al., 2016; Jia et al., 2016).

In contrast, comparison theories, which includes social comparison theory (Festinger, 1954), equity theory (Adams, 1965) and relative deprivation theory (Martin, 1981), have been widely used in organizational research to explain individual reactions to pay. Individuals expect rewards 
to be distributed commensurate with their own contribution and evaluate themselves (the equity of their exchange relationships with their firms) by comparing with reference groups. If their input-outcome ratios are lower than those of the reference groups, the feelings of inequity or deprivation would be stronger (Festinger, 1954; Adams, 1965; Martin, 1981). Moreover, individuals attempt to resolve the tension generated by inequity by modifying their feelings about either their own or their reference group's inputs and/or outcomes, by changing their actual inputs (e.g., reducing work effort and/or attendance rate) or outcomes (e.g., asking for extra compensation), by terminating perceived inequitable relationships (e.g., leaving their organizations), or even retaliating regardless of their own welfare (Cowherd and Levine, 1992). Researchers have found that increased pay dispersion in organizations is associated with higher managerial turnover, less collaboration and lower productivity (Bloom and Michel, 2002; Firth et al., 2015). Thus, perceived inequity caused by large management-employee pay gaps may lead to costly behavior that impedes firm innovation.

Therefore, it is an empirical issue to investigate which channels dominate the relationship between pay gap and firm innovation. We conduct this study using the data from China that is a particularly appropriate setting for this research because of data availability ${ }^{4}$. Publicly traded firms in China have to disclose information regarding salary expenses to employees. With this information, we can construct the pay gap ratio of all listed firms. Therefore, this study is likely free of selection bias. Although we use Chinese data in this study, the insights gained from our evidence are not limited to the Chinese market. In effect, governments in both developed markets, such as the US, and in developing countries, such as China, have realized the importance of fairness and have established a ceiling for CEO compensations when confronted with large pay

\footnotetext{
${ }^{4}$ Faleye et al. (2013) conduct their study based on U.S. data, however, only $18 \%$ firms had disclosed the wage information of the employees and firms reporting wages are not a random sample (Cronqvist et al., 2009).
} 
disparities.

To assess this relationship, we regress firm innovation on firm pay gaps. We measure innovation outputs using patent application data. Due to its left-censored nature, we use the Tobit model regression. In the baseline tests, we come to the conclusion that pay gaps promote firm innovation after controlling a series of firm and industrial characteristics. Considering the competing theoretical effects of the tournament theory and comparison theories about pay gaps, we construct a quadratic model to further test if there is a nonlinear relationship between pay gaps and innovation output and the result shows an inverted-U pattern, indicating that the tournament theory and the comparison theories dominate in the small and large pay gap stage respectively. However, a subsample of large pay gaps does not reveal a significant negative effect of pay gaps on innovation output, suggesting that the positive linear association between pay gaps and innovation is relatively reliable.

To identify the causality, we use the minimum wage at the provincial-level as an instrument variable of firm pay gap. As Draca et al. (2011) argues, minimum wage adjustments increase the wages of the low paid. For firms residing in the policy-related area, a rise in minimum wage, which is closely correlated with employee pay, would result in a decrease in the pay gap between management and ordinary employees. Unsynchronized provincial minimum wage adjustments are not at the local level and are less likely to be influenced by firms in a county (Gan et al., 2016), in other words, they should not be directly related to firm innovation. Hence, provincial minimum wage satisfies the relevance and validity criteria and serves as an appropriate instrument variable for firm pay gaps. After addressing the potential endogenous problems, our baseline conclusion was consistent.

To check the robustness, we do some additional tests. First, we employ R\&D expenditure as 
alternative proxy for innovation in baseline model. Second, we examine the influence in technology-intensive industries. Third, we conduct the 2SLS regressions using the post-2004 subsample in consideration of the enforcement change of minimum wage policy after 2004. All these results are consistent with baseline ones.

To further investigate the source of innovation incentives, we divide firm pay gaps into three components: management pay premiums, employee pay premiums and industry pay gaps, and try to separate the effects of management pay premiums from employee pay premiums. We find that management pay premiums enhance innovation while employee pay premiums impede innovation. We further examine the moderating effects of human capital. The results show that in firms with higher human capital, the positive effect of management pay premium is greater while the negative effect of employee pay premium is smaller, which shows that on the one hand, employees with higher level of human capital are more collaborative, competent and motivated in implementing innovation decisions made by the management groups, whereas on the other hand, high premiums on employee pay may be a waste of resources, especially for low human-capital workers. In this sense, employee pay premiums are more detrimental to firms whose capital allocation is more crucial. Thus, we compare the effects of employee pay premiums on innovation in SOEs with Non-SOEs in consideration of their difference in financing constraints and find that employee pay premiums impede innovation significantly only in Non-SOEs, which confirms our conjecture that employee pay premium divert physical resources from innovation activities and provides complementary evidence for the economic consequences of financing discrimination in Non-SOEs.

This paper makes possible contributions in two ways. First, we examine the effects of 
intra-firm pay dispersion on innovation at the firm-level in a transitional economy ${ }^{5}$, combine the managerial and employee incentives in innovation process, and complement the emerging literature focusing on the determinants of firm innovation theoretically (Manso, 2011) and empirically (Lerner et al., 2011; Aghion et al., 2013; Ederer and Manso, 2013; He and Tian, 2013; Chemmanur et al., 2014; Tian and Wang, 2014; Bernstein, 2015; Chang et al., 2015; Tan et al., 2015; Bradley et al., 2016; Jia et al., 2016).

Second, we explore the possible underlying mechanism of how the pay gap affects firm innovation output. The division of the pay gap into management pay premiums and employee pay premiums and the moderating effects of human capital and firm ownership help us understand the different roles that management and ordinary employees play in innovation activities.

Third, we provides empirical tests on the real effects of policies and acts focusing on income equity from the perspective of firm innovation, and the conclusions have clear implications on the trade-off between justice and efficiency for government and business sectors.

The rest of this paper is organized as follows: section two describes the data and the variables, section three presents and analyzes the empirical results, section four explores the potential mechanisms, and section five is the conclusion.

\footnotetext{
5 To the best of our knowledge, there are three studies that pay attention to the real effects of the pay gaps between top managers and ordinary employees. Faleye et al. (2013) find that the pay gap between CEOs and employees promotes firm value and operating performance. However, they based their study on U.S. data, and only $18 \%$ of firms had disclosed the wage information of their employees. Therefore, their results suffer from severe self-selection bias. Based on the data of Chinese listed firms, Banker et al. (2016) find that the pay gap between management groups and employees improves firm performance and the positive effect is largely driven by management pay premiums. Firth et al. (2015) conduct their research using Chinese data as well and find that pay gaps between top management and workers are negatively associated with productivity and non-state ownership alleviates the negative effect. However, the endogenous issue was not addressed in these two papers.
} 


\section{Data and Variables}

\subsection{Sample}

Our sample is based on Chinese listed firms during the 2000-2012. The firm patent information is obtained from the Chinese Patent Database collected by He et al. (2013) and Tong et al. (2014), which is developed from patents filed with China's State Intellectual Property Office (SIPO). The data matches patents without firm identifiers to the listed firms and subsidiaries, so that the patent data could be used to link to other firm-level data. An obvious advantage of this database is their consideration of name changes and comprehensive coverage of subsidiaries, which guarantees the continuity and accuracy of the data. The Chinese Patent Database provides listed firms' patent information during its IPO year to 2010, and subsequent data in 2011 and 2012 is complemented following the matching methodology reported in He et al. (2013). Financial data and corporate governance information about the listed firms are mainly obtained from the China Stock Market \& Accounting Research (CSMAR) database and supplemented by WIND database. We also exclude firms from the financial industry.

\subsection{Variables}

\subsubsection{Measuring Innovation}

In this paper, we use patent-based metrics to measure firm innovation. This approach prevails in recent research (Acharya and Subramanian, 2009; Lerner et al., 2011; Aghion et al., 2013; He and Tian, 2013; Chemmanur et al., 2014; Tian and Wang, 2014; Bernstein, 2015; Boasson and Boasson, 2015; Chang et al., 2015; Tan et al., 2015; Bradley et al., 2016; Jia et al., 2016) and is superior to earlier studies that mainly use R\&D expenditures to gauge firm innovation for a lot of reasons. First, patenting activity and the characteristics of patents reflect firms' innovation output 
that encompasses the successful resource integration and team cooperation rather than merely R\&D expenditures which may be wasteful and be of low yield (Lerner et al., 2011; Jia et al., 2016). Second, R\&D spending is sensitive to accounting norms, particularly the debating whether it should be capitalized or expensed (Acharya and Subramanian, 2009). Finally, the Chinese listed firms have not disclose R\&D expenditures in financial statements until 2009 and more than $30 \%$ of firm-year observations have missing values of R\&D expenditures during the year 2009-2012; however, missing R\&D expenditures in this accounting item do not necessarily indicate a lack of innovation activity, simply setting the missing value as zero may lead significant bias in the findings (Koh and Reeb, 2015; Jia et al., 2016). Thus, patent-based metrics which are free of selective disclosure like $R \& D$ expenditures are better indicators of firm innovation performance.

According to Chinese patent law, patents are classified into three types: (1) invention patents, (2) utility model patents, and (3) design patents. Invention patents are granted to new technical solutions to a product or process, or to their improvement. Utility model patents are granted to new practical technical solutions to the shape, structure or a combination of both of a product. Design patents are granted to new designs relating to shape, pattern, color or a combination that are aesthetically satisfactory and industrially applicable.

The Chinese Patent Database developed by He et al. (2013) provides the numbers of applications filed by the listed companies and their subsidiaries of each type separately, the number of applications that have been granted (invention patent only), and the number of granted patents that have expired due to them reaching the full term or the renewal fees not being paid by the end of their observation period (January, 2012).

Following earlier innovation studies using patent-based metrics (e.g. He and Tian (2013), 
Chemmanur et al. (2014), Chang et al. (2015), Tan et al. (2015)) and combined with the availability of patent information in SIPO database, we construct three measures of innovation output based on firms' patent applications. We do not use the patent grant data due to its sensitivity to the observation time, bureaucratic factors and the uncertainty of substantive examination. Moreover, the application year better captures the actual time of innovation (Griliches et al., 1988; Hall et al., 2001). To deal with the right skewness of patent data, we use the natural logarithms of one plus raw patent application data as the final innovation measures in the analysis.

Specifically, we define the aggregate applications of three types of patents each firm filed in each year as the total innovation output (Patent). Among the three types of patents, invention patents are the most original, utility model and design patents generally represent small and incremental innovations (He et al., 2013). Therefore, we extract the number of invention patent applications a firm filed (Patent1) and used it as a proxy for innovation quality since the raw data from the SIPO database did not provide information on patent citations. For completeness, we also add up the applications of utility model and design patents as a proxy for innovation quantity (Patent23).

\subsubsection{Measuring Pay Gap}

Following Faleye et al. (2013) and Banker et al. (2016), we describe firm pay gap (FPG) as the average management pay to the average employee pay, where management includes all the executives, directors (except independent directors) and supervisors, and employee includes all other employees (ordinary/rank-and-file employees/workers). The compensation information was disclosed in firms' annual reports.

Specifically, we define the average management pay $(A M P)$ as the sum of salaries, bonuses, 
and all other compensation for management divided by management size. Unlike the US, stock options for executives were not permitted until 2006 and the trading of stock holdings was not deregulated until early 2000s, both the coverage and the ratio of compensation in the form of stocks or stock options are very small in Chinese listed firms (Bryson et al., 2014). Therefore, we do not take stock-based compensation into consideration ${ }^{6}$. Management size equals the total number of executives, directors, supervisors, except those who do not get paid, and independent directors.

Similarly, the average employee pay $(A E P)$ is calculated as the total salary expense for ordinary employees, which equals to the total salary expense for all employees minus that of management, divided by the number of ordinary employees.

Finally, we obtain the key independent variable $F P G$ by calculating the ratio of $A M P$ and $A E P$.

\subsubsection{Measuring Control Variables}

Based on previous innovation literature, we control a vector of firm and industry characteristics that may affect a firm's future innovation output, including firm size, leverage, profitability, asset tangibility, firm age, sales growth, industry concentration, independent director ratio, management shareholding ratio and two dummy variables, State-ownership and CEO duality. We provide detailed variable definitions in Panel A of Table 1.

\subsection{Summary Statistics}

To minimize the effect of outliers, we winsorize all the continuous variables at the $1^{\text {st }}$ and $99^{\text {th }}$ percentiles. Table 1 Panel B provides descriptive statistics of the variables. On average, a firm in our sample filed 8.002 patent applications per year, including 2.521 invention patent applications and 5.212 patent applications of the other two types. The average firm pay gap is 4.579 , which is

\footnotetext{
${ }^{6}$ But we control the management shareholding ratio in all the regressions.
} 
significantly lower than the CEO-employee relative pay (in cash) in the U.S. (Faleye et al., 2013).

\section{/ Please insert Table 1 here/}

\section{Empirical Results and Analysis}

\subsection{Baseline Results}

To assess the effects of firm pay gaps on innovation, we estimate various forms of the following equation using the Tobit model:

$$
\text { Innovation }_{i, t+1}=\alpha+\beta F P G_{i, t}+\gamma \text { Controls }_{i, t}+\sum \text { Year }+\sum \text { Industry }+\varepsilon_{i, t}
$$

where $i$ indexes firm and $t$ indexes time. The dependent variable Innovation refers to innovation output measures (LnPatent, LnPatent1 and LnPatent23). LnPatent is the natural logarithm of one plus the total applications of invention, utility models, and design patent that a firm filed. Similarly, LnPatent 1 is the natural logarithm for the total applications of invention patents and LnPatent23, of utility model and design patents. The three variables represent the total innovation output, innovation quality and innovation quantity respectively. Since the innovation process generally takes time, we examine the effects of a firm's pay gap on its innovation outcomes one year ahead..$^{7}$ The firm pay gap, FPG, measures the pay dispersion between management and employees in a firm. Controls denotes a vector of control variables, including firm and industry characteristics that may affect a firm's innovation output. $\sum$ Year captures the year's fixed effects and $\sum$ Industry captures industry fixed effects.

\footnotetext{
${ }^{7}$ To capture the fact that different innovation processes take different lengths of time and may be longer than one year, we examine the effect of firm pay gaps on patent applications two, three and four years ahead, and obtain both quantitatively and qualitatively consistent results. Moreover, the effects of firm pay gaps on the accumulated patent applications two, three or four years ahead are also similar.
} 
We take LnPatent, LnPatent1 and LnPatent 23 as dependent variables respectively. The results are reported in Table 2. All the coefficients of $F P G$ are positive, with the coefficients in Reg-1 and Reg-3 being significant at the 99\% confidence level and Reg-2 at 90\% confidence level. This means that the firm pay gap can enhance innovation outputs, both innovation quality and quantity. Therefore, the results support the tournament theory, suggesting that the firm pay gap enhances innovation efforts. This is also consistent with previous empirical research which found evidence that pay gaps are positively associated with firm performance (Lallemand et al., 2004; Kale et al., 2009; Banker et al., 2012; Jia et al., 2016). With regards to control variables, innovation outputs in SOEs are more abundant than Non-SOEs. Firms that are of larger size or firms with lower leverage, higher profitability, lower sales growth, higher independent-director ratio, higher management holding ratio, and which are younger and managed by a chairman, filed more patent applications.

/Please insert Table 2 here/

\subsection{The Non-linear Effect}

Although the above linear model shows a positive relationship between firm pay gaps and innovation outputs, it simply reflects only the net effect, the existing theories have different conclusions on the economic consequences of firm pay gaps. From the perspective of the tournament theory, firms can motivate employees by setting up a hierarchy of compensation (prize salary), with some employees obtaining wages greatly above their presumed marginal products and others below. In comparison to the optimal piece rate, which is thought to be fair, the prize salary structure tends to dominate in fields that have a higher degree of inherent risk 
(e.g., R\&D) (Lazear and Rosen, 1981). Under this salary system, employees are motivated by the compensation of those at their own level and those at the next higher level in the organizational hierarchy (Rajgopal and Srinivasan, 2006); therefore, a large pay gap would enhance efforts from both the management groups and ordinary employees. However, comparison theories hold different views. According to them, employees may perceive deprivation or unfairness from a large pay dispersion (Martin, 1981), resulting in a decrease in their work efforts and collaboration desire or an increase in turnover rate or absenteeism (Cowherd and Levine, 1992), which would be harmful to innovation. Considering the competing effects of these theories, we try to further analyze the positive net impact of firm pay gap on innovation and construct a quadratic model to explore whether there is an optimal pay gap which maximizes innovation.

$$
\text { Innovation }_{i, t+1}=\alpha+\beta F P G_{i, t}+\delta F P G_{i, t}^{2}+\gamma \text { Controls }_{i, t}+\sum \text { Year }+\sum \text { Industry }+\varepsilon_{i, t}
$$

where the quadratic item represents a non-linear relation between firm pay gap and innovation. Given that the coefficient of $F P G$ is positive, the coefficient of $F P G^{2}$ is also positive, meaning that the relationship between firm pay gap and innovation is a parabola going upwards, with a larger firm pay gap corresponding to higher innovation and the curve becoming steeper as pay gap increases, that is, that the marginal innovation outputs of the pay gap increases. If the coefficient of $F P G^{2}$ is negative, then the relationship between firm pay gap and innovation is a parabola going downwards, as pay gap increases, innovation outputs rise in the first stage then decrease, that is, that the marginal innovation output of the pay gap decreases.

Table 3 presents the results of this non-linear model. The coefficient of $F P G^{2}$ in $R e g-1$ is significantly negative, which shows a relationship between FPG and LnPatent with a parabola going downwards (an inverted-U). In $\operatorname{Reg}-2$ and $\operatorname{Reg}-3$, the coefficients of $F P G^{2}$ show a relationship between FPG and LnPatent1 or LnPatent23 presenting a similar tendency. The 
inverted-U relationship shows that there is a critical value of firm pay gap, under which the pay gap enhances innovation (the marginal innovation output of the pay gap is greater than 0) and above which it impedes innovation (the marginal innovation output of the pay gap is less than 0). This indicates that there is a trade-off between the tournament theory and the comparison theories, the former dominates in the small pay gap situation and the latter in the large pay gap situation.

\section{/ Please insert Table 3 here/}

Furthermore, we partition the sample into three subsamples according to the value of the pay gap, with each group having almost the same number of observations. The results of the model (1) for small/large pay gap groups and each independent variable are reported in Table 4 respectively. The regression coefficients of $F P G$ show that firm pay gaps enhance innovation significantly in the small pay gap subsample, but impedes innovation in the large pay gap subsample. Based on these findings, we come to a conclusion that the tournament theory dominates in innovation activities, but the effects of the comparison theories become apparent as pay gap increases. In the end, it presents net effect of the tournament theory in the small pay gap stage and the comparison theories in the large pay gap stage, but the latter is not statistically significant. Taken together, the linear relationship between pay gap and innovation is relatively reliable.

/ Please insert Table 4 here/ 


\subsection{Endogeneity}

While we document a positive association between firm pay gap and innovation outputs, the results are potentially subject to endogeneity, we still need to identify the causal effect of pay gaps on innovation outputs. Firstly, expected changes in a firm's innovation output may cause its inclusion in the compensation policy, leading to a reverse causality concern. On the one hand, firm pay gaps can enhance firm innovation; on the other hand, firm innovation can also widen the pay gap between management and employees. For example, firms with higher innovative ability may be more profitable and provide higher rewards for management, or for both management and employees but changes in management pay are more substantial. Secondly, omitted variables that simultaneously affect pay gap and innovation output could also result in a spurious causality between pay gap and innovation, such as brain gain in management or/and employees. Therefore, a correlation between pay gaps and innovation output may tell us little about the causal effects of pay gaps on innovation. In this part of the study, we introduce an instrumental variable and a two-stage least squares (2SLS) specification to address the possible endogeneity issue.

Specifically, we took provincial minimum wage as the instrument variable. Early in 1994, the Chinese government has started to implement a minimum wage policy in various cities across the country. However, the minimum wage adjustment was less frequent in China before 2003; especially in 1998, during the Asian financial crisis, only one-fifth of all counties adjusted their minimum wages (Huang et al., 2014). In March 2004, the Ministry of Labor and Social Security passed additional regulations to further intensify the minimum wage policy, which formalized and regularized the process of minimum wage adjustment; by the end of 2004, the minimum wage system was established in the whole country, provincial governments are 
required to adjust their minimum wage standards at least once every two years (Gan et al., 2016). We adopt the provincial minimum wage as the instrument variable for firm pay gaps for the following reasons. First, the minimum wage policy is aimed at protecting the minimum income of laborers, narrowing the residents' income gap and maintaining social fairness rather than motivating innovation, minimum wage adjustments may make firms more aware of income equality. There is also evidence that national minimum wage policies increase the wages of the lower paid employees (Draca et al. 2011). Therefore, the minimum wage adjustments affect the salaries of ordinary employees and not of the management, lead to reductions in the firm pay gaps; Second, provincial governments adjust the standards of minimum wage according to their own realities, the adjustments are made at the provincial level rather than the local level and are less likely to be significantly influenced by firms in a county (Gan et al., 2016). Hence, unsynchronized provincial minimum wage adjustments do not directly correlate with firm innovation. To sum up, the variable provincial minimum wage (Minwage) satisfies the relevance and validity criteria necessary for an appropriate instrument for firm pay gaps.

Therefore, in this subsection, we conduct a 2SLS model to correct for the potential bias due to endogeneity in firm pay gap.

Table 5 presents results from estimating the 2SLS specification with Minwage as the instrument variable. The first column of the table reports the results from the first-stage regression estimating equation $(3)^{8}$ and the last three columns reports the results from the second-stage regression estimating equation (1) with different measures of innovation outputs.

$$
F P G_{i, t}=\alpha_{0}+\beta_{0} \text { Minwage }_{i, t}+\gamma_{0} \text { Controls }_{i, t}+\sum \text { Industry }+\varepsilon_{i, t}
$$

Different provinces adjusted their minimum wage level in different years and with different

\footnotetext{
${ }^{8}$ Year effect was not included because the trend of minimum wage was monotonically non-decreasing. We also try to take the value of $F P G$ for the next year as a dependent variable and still obtain a consistent result.
} 
frequencies. For a province adjusting its minimum wage in a given year, we take the adjusted value as Minwage; for those who did not adjust their minimum wage in that year, we take the value for the previous year as Minwage. We also follow Acemoglu et al. (2001) to examine whether Minwage satisfies the exclusion restriction. In particular, we add Minwage into the baseline model and re-estimate the regressions, the results are shown in Table A2. The coefficients of $F P G$ are consistent with our baseline model, and the minimum wage has no significant effect on firm innovation, which indicates the satisfaction of exclusion condition.

In Reg-1, the coefficient estimate of Minwage is negative and significant at the $1 \%$ level, suggesting that an increase in the minimum wage reduces the firm pay gap. This is consistent with our conjecture that minimum wage is closely and positively related to employee pay. The F-statistic of the instrument variable is quite large and significant at the $1 \%$ level, which means that the instrument variable is highly correlated with FPG. Based on the rule-of-thumb with one instrument for one endogenous variable, we reject the null hypothesis that the instrument is weak. Therefore, the coefficient estimates and their corresponding standard errors reported in the second stage are likely to be unbiased and inferences based on them are reasonably valid.

Reg-2 presents the results with LnPatent as the dependent variable, and Reg-3 and Reg-4 with LnPatent1 and LnPatent23 as the dependent variables respectively. Consistent with the results from the baseline model analysis, the estimated coefficients of $F P G$ are all significantly positive. Therefore, the identification test based on the instrument variable approach reported in this subsection confirms that there is a positive causal effect of firm pay gaps on firm innovation.

As for the economic significance, we can infer from the coefficient of FPG. For example, as firm pay gap rises from the median (3.484) to the upper quartile (5.769), the logarithmic total patent application would increase 1.324, which means that the number of total patent application 
plus 1 increases $275.67 \%$.

/Please insert Table 5 here/

\subsection{Robustness Checks ${ }^{9}$}

In this subsection, we conduct some additional tests to show the robustness of our results. First, we use R\&D expenditure as proxy of innovation; second, we examine the effect of firm pay gap on firm innovation in technology-intensive industries; third, we conduct the 2SLS regressions using the subsample of post-2004.

\subsubsection{Alternative Proxy for Innovation}

In the literature, there are mainly two measures for firm innovation: first, R\&D expenditure, which is common in early studies, measures a firm's innovation input; second, patents, denoting innovation output. In subsection 2.2.1, we have discussed that $R \& D$ expenditures is inferior to the patent-based metrics to gauge firm innovation, in spite of this, we use it to conduct robustness test and find a positive effect of firm pay gap on $R \& D$ expenditure, which is consistent with the coefficients in Table 2, suggesting that the positive effect of pay gap on innovation is robust to alternative measure of innovation. The results are reported in Table 6.

\section{/ Please insert Table 6 here/}

\subsubsection{Industries with Different Technology-Intensiveness}

From Table 1, we can see that less than half of the firms in our sample had filed patent

\footnotetext{
9 We thank the referee' comments for raising the robust examinations.
} 
applications in the data period. Moreover, the distribution of patents is very different from industry to industry. Therefore, we conduct a test to see if our results are robust in technology-intensive industries. Specifically, we regard those industries whose patent application's median is 1 or average application is above 10 as technology-intensive industries. It seems that these industries are more inclined to use patent as a way to protect firm innovation. We re-do the baseline analysis using this subsample and find that the results presented in Table 7 are consistent.

\section{/ Please insert Table 7 here/}

\subsubsection{The Minimum Wage Regulations in 2004}

According to Fang and Lin (2015) and Gan et al. (2016), China's first national minimum wage policy was issued in 1993, but minimum wage adjustment was less frequent in China before 2003. "The Minimum Wage Regulations" were passed by the Ministry of Labor and Social Security in December 2003 and put into effect since March 2004. To ensure the enforcement of the regulations, penalties for violation increased four times to a new interval (100-500\% of the owed wages). Therefore, 2004 are likely to be the year around which the enforcement of minimum wage policy changed. We take the year of 2004 as a watershed and divide the whole sample into two subsamples, pre-2004 and post-2004, to examine the effect of minimum wage on firm pay gap respectively. The results show that, before 2004, minimum wage has little significant influence on firm pay gap, but negatively affects pay gap in and after 2004. Then we choose the subsample of post-2004 to do robustness check for the 2SLS regressions, the results from the second step are consistent with those using the whole sample and baseline results using 
post-2004 subsample, supporting the positive effects of pay gaps on firm innovation. The results from the first stage regression of pre- and post-2004 and second of post-2004 are presented in the table $8 .^{10}$

/ Please insert Table 8 here/

\section{Possible Mechanisms}

\subsection{Division of Pay Gap}

In this subsection, we explore the possible underlying mechanisms through which the firm pay gaps may affect innovation outputs. To identify the source of innovation incentives induced by firm pay gaps, whether comes from the managers or employees, we divide the pay gap into different parts. Given that the comparisons may lie between the management and employees in the same firm, between management and their peers in the same industry, and between employees in different firms of the same industry, we accordingly divided the pay gap into the following three parts.

$$
\text { Firm Pay Gap }=\frac{\text { Management Pay Premium }}{\text { Employee Pay Premium }} * \text { Industry Pay Gap }=\frac{M P P}{E P P} * I P G
$$

where, Management Pay Premium (MPP) is the ratio of Average Management Pay (AMP) to its industry-year median value and reflects the comparison between management and their peers in the same industry, Employee Pay Premium (EPP) is the ratio of Average Employee Pay (AEP) to its industry-year median value and reflects the comparison between employees in different firms of the same industry, and Industry Pay Gap $(I P G)$ is the ratio of the industry-year median value of Average Management Pay and Average Employee Pay. In particular, the above three parts are

\footnotetext{
${ }^{10}$ For brevity, the baseline regressions' results of the post-2004 subsample are omitted.
} 
defined as:

$$
\begin{aligned}
& M P P=\frac{A M P}{\text { Industry-year median of } A M P} \\
& E P P=\frac{A E P}{\text { Industry-year median of } A E P} \\
& I P G=\frac{\text { Industry-year median of } A M P}{\text { Industry-year median of } A E P}
\end{aligned}
$$

Our baseline model can then be extended to the following form:

$$
\begin{aligned}
\text { LnPatent }_{i, t+1}= & \alpha+\beta_{1} \text { MPP }_{i, t}+\beta_{2} \text { EPP }_{i, t}+\beta_{3} I P G_{i, t} \\
& +\gamma \text { Controls }_{i, t}+\sum \text { Year }+\sum \text { Industry }+\varepsilon_{i, t}
\end{aligned}
$$

Regression results are reported in Table $8^{11}$. Each coefficient of $M P P$ is positive and significant at the $1 \%$ level in three specifications, which is consistent with Lin et al. (2011) who found that managerial incentives increase both firm innovation inputs and outputs, indicating that management pay premium alleviate the agency problems and encourage the management focus more on the long-term interests of firms. Coefficients of EPP are negative and significant at the 5\% level in $\operatorname{Reg}-1$ and $R e g-3$, but insignificant in $R e g-2$, indicating that employee pay premiums only reduce innovation quantity, but not innovation quality. Compared the coefficients of MPP and EPP, we find that management pay premium is the dominant factor which drives firm pay gap to enhance innovation. As Bradley et al. (2016) points out, higher wage demands made by workers would lead to an ex ante underinvestment in R\&D. Considering that most employees are homogenous and low-skilled, higher employee pay means a waste of resources, which may divert physical resources away from $\mathrm{R} \& \mathrm{D}$ and thus be harmful to innovation activities. Moreover, insignificant effects in innovation quality is consistent with the fact that invention patents involve

\footnotetext{
11 In this subsection, since that we divide pay gap into three components, and one IV in constructed, we therefore do not report the IV regression. Please be cautious when interpreting the causality of our results in this subsection.
} 
the most originality and technological advancements; correspondingly, this type of innovation activity requires workers with higher human capital, either higher education or higher skill levels, and higher pay should be provided for them. Therefore, employee pay premiums don't influence the innovation output measured by invention patent applications significantly. To some extent, the more original the patents are, the more they are subjected to the $R \& D$ decisions made by management. Because the process of invention patents is time-consuming, with lack of support, it would be given up halfway. This also strengthens the effects of management pay premiums; in contrast, the low-quality innovation activities involve more homogeneous and low-skilled workers, leading to the more negative effect of employee pay premium on innovation quantity. If this opinion holds, then the negative effects of employee pay premiums on innovation would reduce as the employee human capital improves. We therefore partition the whole sample into three groups according to the industry-year rank of human capital level of each firm to verify this conjecture.

\section{/ Please insert Table 8 here/}

\subsection{Effects of Human Capital}

In the previous subsection, we found that management pay premiums enhance both the quantity and quality of innovations, while employee pay premiums impede only the quantity of innovation. Therefore, it is necessary for us to investigate why the role of employee pay premiums is different in the quantity and quality of innovations. We conjecture that high pay premiums for homogenous and low-skilled employees are misallocation of resources as it crowds out R\&D expenditure and reduces innovation output. Furthermore, human capital may weaken 
the negative effects of employee pay premiums on innovation. In this subsection, we attempt to examine the above conjecture by comparing the effects of employee pay premiums in the subsample with different levels of human capital.

To conduct the empirical test, we partition all firms into three groups based on the industry-year rank of human capital, with each group containing almost the same number of observations. Specifically, we use the ratio of employees ${ }^{12}$ who have masters or doctorate degree as the human capital. In the low-HC subsample, observations are for those who are in the first tertile of industry-year rank of human capital, and high-HC subsample for those in the top tertile. For both subsamples, we repeat the regression using equation (8) separately, and results are reported in Table $10 .^{13}$

From Table 10, we find that the coefficients of EPP is only significant in low-HC subsample, indicating that the negative effect of employee pay premium is driven by the negative role of employees with low human capital, which is consistent with our conjecture above and indicates that higher pay for homogenous and low-skilled employees is a waste of limited resources and harmful to innovation.

Moreover, the comparison of the effect of employee pay premiums for employee with different human capital also suggests that high pay premium for employees with low human capital sounds resource misallocation. As Banker et al. (2016) argues, efficiency wage theory is unlikely to be applicable to Chinese firms offering above-industry-average pay for low skilled

\footnotetext{
${ }^{12}$ Here, the top executives were included in the employees because we were not able to extract data for ordinary employee education levels. Intuitively, the education level of the top executives was generally high, and its variance among firms was relatively smaller than the variance of ordinary employees. Based on these two reasons, the human capital order of employees (including top executives) would be highly similar to that of ordinary employees to a large extent.

${ }^{13}$ For robustness, we also interact the variables of interest (i.e. $M P P, E P P$ and $I P G$ ) with the channel variable, $H C$, and the results are included in Table 10. The coefficients of the interactions support the differences across subsamples, suggesting that the negative effects of EPP are more pronounced in firms with lowed human capital.
} 
labor, wage premiums for such employees would reduce firm performance and firm value. Our test in this subsection provides evidence to back up this argument from the perspective of firm innovation.

/ Please insert Table 10 here/

\subsection{Effects of Ownership}

Thus far, we show that employee pay premiums impede innovation outputs and the possible mechanism may be that excessive employee pay leads to a waste of resources by crowding out innovation input and even affecting R\&D decisions. Considering the current situation in China where SOEs are favored by the capital market, both credit and equity markets, and where Non-SOEs are subjected to higher financing constraints (Wong, 2014), we suppose that capital allocation in Non-SOEs are more crucial than in SOEs. As a result, the negative effects of excessive employee pay on innovation activities, which need long-term investments and are full of uncertainty, should be more pronounced in Non-SOEs.

To test the aforementioned idea, we partition the whole sample into two subsamples according to their ownership, SOEs and Non-SOEs, and regress equation (8) for each subsample once again.

Regression results are reported in Table 11. Consistent with our expectations, the coefficients of EPP are only significantly negative in the Non-SOE subsample, indicating that excessive employee pay crowds out innovation inputs and reduces innovation outputs in private enterprises. On the contrary, SOEs have advantages in physical capital and are not so restricted when it comes to resource misallocation as Non-SOEs. Meanwhile, innovation activities are 
closely and positively related to $M P P$, and the effects are pronounced in both SOEs and Non-SOEs, which suggests that management pay premiums are universally effective in alleviating the agency conflicts, avoiding managerial myopia and thus enhancing firm innovation. $^{14}$

\section{/ Please insert Table 11 here/}

\section{Discussion and Conclusion}

In this paper, we investigate the causality between pay gaps and firm innovation. We find that pay gaps significantly improve innovation, confirming that the tournament theory dominates in innovation activities. This result is confirmed by the non-linear model test and instrument variable identification, and is also robust to alternative proxy for innovation and subsample of technology-intensive industries. The division of firm pay gap shows that high management pay premiums provide incentives for management to devote to innovation activities and improve innovation quality and quantity, while pay premiums for ordinary employees lead to a reduction in innovation quantity. Moreover, the negative effects of employee pay premiums are more pronounced when human capital is relatively low or when firms are from the private sector. The results indicate that all kinds of innovation activities need proper $R \& D$ decisions made by management, rational capital allocation and active collaboration between the management and rank-and-file employees.

This conclusion provides clear policy implications. Making proper pay packets and keeping a relatively big pay gap between management and employees is beneficial for firm innovation.

\footnotetext{
${ }^{14}$ Likewise, we interact the variables of interest (i.e. $M P P, E P P$ and $I P G$ ) with the channel variable, $S O E$, and the results are included in Table 11. The coefficients of the interactions support the differences across subsamples, suggesting that the negative effects of $E P P$ are more pronounced in private enterprises.
} 
Especially for firms with a large number of homogenous and low-skilled workers or firms in the private sector, it is not advisable to set the employee wages above its corresponding industry medium level.

Although our findings are consistent with the tournament theory, we cannot rule out the possible negative effects of the pay gap on firm innovation, as suggested by the comparison theories. The reason is that our evidence only reflects the "net" effects of pay gaps on firm innovation. In fact, pay gaps may play both a positive and negative role in motivating firm innovation but the latter is dominated by the former.

\section{References}

[1] Acemoglu, D., S. Johnson, and J. A. Robinson, 2001, The colonial origins of comparative development: An empirical investigation. American Economic Review 91, 1369-1401.

[2] Acharya, V., Subramanian, K.V., 2009. Bankruptcy Codes and Innovation. Review of Financial Studies 22(12), 4949-4988.

[3] Adams, J.S., 1965. Inequity in Social Exchange. Advances in Experimental Social Psychology 2, 267-299.

[4] Aghion, P., Van Reenen, J., Zingales, L., 2013. Innovation and Institutional Ownership. American Economic Review 103(1), 277-304.

[5] Banker, R. D., D. Bu, and M. Mehta, 2016, Pay gap and performance in China, Abacus 52, 501-531.

[6] Barker III, V.L., Mueller, G.C., 2002. CEO Characteristics and Firm R\&D Spending. Management Science 48(6), 782-801.

[7] Belloc, F., 2012. Corporate Governance and Innovation: A Survey. Journal of Economic Surveys 26(5), 835-864.

[8] Bernstein, S., 2015. Does Going Public Affect Innovation? Journal of Finance 70(4), 1365-1403.

[9] Bloom, M., Michel, J.G., 2002. The Relationships among Organizational Context, Pay Dispersion, and among Managerial Turnover. Academy of Management Journal 45(1), 33-42.

[10] Boasson, V., and Boasson, E., 2015. Firm Value, Spatial Knowledge Flow, and Innovation: Evidence from Patent Citations. China Finance Review International 5(2), 132-160.

[11] Bradley, D., Kim, I., Tian, X., 2016. Do Unions Affect Innovation? Management Science, Accepted.

[12] Bryson, A., Forth, J., Zhou, M., 2014. Same or Different? The CEO Labour Market in China's Public Listed Companies. Economic Journal 124(574), F90-F108.

[13] Chang, X., Fu, K., Low, A., Zhang, W., 2015. Non-executive Employee Stock Options and Corporate Innovation. Journal of Financial Economics 115(1), 168-188. 
[14] Chemmanur, T.J., Loutskina, E., Tian, X., 2014. Corporate Venture Capital, Value Creation, and Innovation. Review of Financial Studies 27(8), 2434-2473.

[15] Cowherd, D.M., Levine, D.I., 1992. Product Quality and Pay Equity between Lower-Level Employees and Top Management: An Investigation of Distributive Justice Theory. Administrative Science Quarterly 37(2), 302-320.

[16] Cronqvist, H., Heyman, F., Nilsson, M., Svaleryd, H., Vlachos, J., 2009. Do Entrenched Managers Pay Their Workers More? Journal of Finance 64(1), 309-339.

[17] Draca, M., Machin, S., Van Reenen, J., 2011. Minimum Wages and Firm Profitability. American Economic Journal: Applied Economics 3(1), 129-151.

[18] Ederer, F., Manso, G., 2013. Is Pay for Performance Detrimental to Innovation? Management Science 59(7), 1496-1513.

[19] Faleye, O., Reis, E., Venkateswaran, A., 2013. The Determinants and Effects of CEO-Employee Pay Ratios. Journal of Banking \& Finance 37(8), 3258-3272.

[20] Fang, T., Lin, C., 2015. Minimum Wages and Employment in China. IZA Journal of Labor Policy 4, 1-30.

[21] Festinger, L., 1954. A Theory OF Social Comparison Processes. Human Relations 7(2), 117-140.

[22] Firth, M., Leung, T., Rui, O., Na, C., 2015. Relative Pay and its Effects on Firm Efficiency in a Transitional Economy. Journal of Economic Behavior \& Organization 110, 59-77.

[23] Gan, L., Hernandez, M.A., Ma, S., 2016. The Higher Costs of Doing Business in China: Minimum Wages and Firms' Export Behavior. Journal of International Economics 100, 81-94.

[24] Griliches, Z., Pakes, A., Hall, B.H., 1988. The Value of Patents as Indicators of Inventive Activity. NBER Working Paper.

[25] Gupta, A.K., Tesluk, P.E., Taylor, M.S., 2007. Innovation At and Across Multiple Levels of Analysis. Organization Science 18(6), 885-897.

[26] Hall, B.H., Jaffe, A.B., Trajtenberg, M., 2001. The NBER Patent Citation Data File: Lessons, Insights and Methodological Tools. NBER Working Paper.

[27] He, J., Tian, X., 2013. The Dark Side of Analyst Coverage: The Case of Innovation. Journal of Financial Economics 109(3), 856-878.

[28] He Z., Tong W., He W., Zhang Y., and Lu J, 2013. Chinese Patent Database User Documentation. https://sites.google.com/site/sipopdb/home/SIPO_listed.

[29] Huang, Y., Loungani, P., Wang, G., 2014. Minimum Wages and Firm Employment: Evidence from China. Available at SSRN.

[30] Jia, N., Tian, X., Zhang, W., 2016. The Real Effects of Tournament Incentives: The Case of Firm Innovation. Available at SSRN.

[31] Kale, J.R., Reis, E., Venkateswaran, A., 2009. Rank-Order Tournaments and Incentive Alignment: The Effect on Firm Performance. Journal of Finance 64(3), 1479-1512.

[32] Koh, P.-S., Reeb, D.M., 2015. Missing R\&D. Journal of Accounting and Economics 60(1), 73-94

[33] Lallemand, T., Plasman, R., Rycx, F., 2004. Intra-Firm Wage Dispersion and Firm Performance: Evidence from Linked Employer-Employee Data. Kyklos 57(4), 533-558. 
[34] Lazear, E.P., Rosen, S., 1981. Rank-Order Tournaments as Optimum Labor Contracts. The Journal of Political Economy 89(5), 841-864.

[35] Lazonick, W., 2003. The Theory of the Market Economy and the Social Foundations of Innovative Enterprise. Economic and Industrial Democracy 24(1), 9-44.

[36] Lee, K.W., Lev, B., Yeo, G.H.H., 2008. Executive Pay Dispersion, Corporate Governance, and Firm Performance. Review of Quantitative Finance and Accounting 30(3), 315-338.

[37] Lerner, J., Sorensen, M., Strömberg, P., 2011. Private Equity and Long-Run Investment: The Case of Innovation. The Journal of Finance 66(2), 445-477.

[38] Lin, C., Lin, P., Song, F.M., Li, C., 2011. Managerial Incentives, CEO Characteristics and Corporate Innovation in China's Private Sector. Journal of Comparative Economics 39(2), 176-190.

[39] Manso, G., 2011. Motivating Innovation. The Journal of Finance 66(5), 1823-1860.

[40] Martin, J., 1981. Relative Deprivation: A Theory of Distributive Injustice for an Era of Shrinking Resources. Graduate School of Business, Stanford University.

[41] Porter, M., 1992. Capital Disadvantage: America's Failing Capital Investment System. Harvard Business Review 70(5), 65-82.

[42] Rajgopal, S., Srinivasan, S., 2006. Pay Dispersion in the Executive Suite. Working Paper.

[43] Rosen, S., 1986. Prizes and Incentives in Elimination Tournaments. The American Economic Review 76(4), 701-715.

[44] Solow, R.M., 1957. Technical Change and the Aggregate Production Function. Review of Economics and Statistics 39(3), 312-320.

[45] Tan, Y., Tian, X., Zhang, X., Zhao, H., 2015. The Real Effects of Privatization: Evidence from China's Split Share Structure Reform. Kelley School of Business Research Paper.

[46] Tian, X., Wang, T.Y., 2014. Tolerance for Failure and Corporate Innovation. Review of Financial Studies 27(1), 211-255.

[47] Wong, T. J., 2014. Corporate Governance Research on Listed Firms in China: Institutions, Governance and Accountability. Foundations and Trends in Accounting 9(4), 259-326. 


\section{Table 1 Variable Definition and Descriptive Statistics.}

Panel A: Variable Definition

This panel reports definitions of the two main variables and other control variables.

\begin{tabular}{|c|c|c|}
\hline Notations & Names & Definitions \\
\hline \multicolumn{3}{|c|}{ Measures of innovation } \\
\hline LnPatent $_{i, t}$ & Total innovation output & $\begin{array}{l}\text { Natural logarithm of one plus the total number of patent } \\
\text { applications of all types filed by firm } i \text { in year } t \text {. }\end{array}$ \\
\hline LnPatent $_{i, t}$ & Innovation quality & $\begin{array}{l}\text { Natural logarithm of one plus the number of invention patent } \\
\text { applications filed by firm } i \text { in year } t \text {. }\end{array}$ \\
\hline LnPatent $23_{i, t}$ & Innovation quantity & $\begin{array}{l}\text { Natural logarithm of one plus the total number of utility model and } \\
\text { design patent applications filed by firm } i \text { in year } t \text {. }\end{array}$ \\
\hline \multicolumn{3}{|c|}{ Measure of firm pay gap } \\
\hline$F P G_{i, t}$ & Firm pay gap & $\begin{array}{l}\text { The ratio of average management pay }(A M P) \text { and average } \\
\text { employee pay }(A E P)\end{array}$ \\
\hline \multicolumn{3}{|c|}{ Measures of other variables } \\
\hline Assets $_{i, t}$ & Total asset & Total assets of firm $i$ at the end of year $t$. \\
\hline Size $_{i, t}$ & Firm size & Natural logarithm of total assets. \\
\hline Leverage $_{i, t}$ & Leverage & The ratio of total asset and total liability. \\
\hline$R O A_{i, t}$ & Profitability & The ratio of net income and total assets. \\
\hline Tangibility $_{i, t}$ & Asset tangibility & (Fixed assets + depreciation)/total assets at the end of year $t$. \\
\hline$A g e_{i, t}$ & Firm age & Number of years since firm's foundation. \\
\hline SalesGrowth $_{i, t}$ & Sales growth & Sales growth rate over the previous year. \\
\hline$H H I_{j, t}$ & Industry concentration & $\begin{array}{l}\text { Herfindahl index of } 4 \text {-digit CRSC industry } j \text { where firm } i \text { belongs, } \\
\text { measured at the end of year } t \text {. }\end{array}$ \\
\hline$S O E_{i, t}$ & State-ownership dummy & $\begin{array}{l}\text { An indicator variable that takes the value of one for firms actually } \\
\text { controlled by the state. }\end{array}$ \\
\hline Dual $_{i, t}$ & CEO duality dummy & $\begin{array}{l}\text { An indicator variable that takes the value of one for firms with } \\
\text { CEO duality. }\end{array}$ \\
\hline IndRatio $_{i, t}$ & Independent directors' ratio & The ratio of independent directors in the board. \\
\hline$M H_{i, t}$ & Management holding ratio & The management shareholding ratio for firm $\mathrm{i}$ in year $\mathrm{t}$. \\
\hline$T M P_{i, t}$ & Total management pay & Total management pay scaled by assets for firm $\mathrm{i}$ in year $\mathrm{t}$. \\
\hline
\end{tabular}


Panel B: Descriptive Statistics

This panel reports the descriptive statistics for variables constructed based on the sample of Chinese listed companies from 2000 to 2012.

\begin{tabular}{lcccccccc}
\hline Variable & Obs. & Mean & SD & P10 & P25 & Median & P75 & P90 \\
\hline Patent & 13410 & 8.002 & 27.154 & 0 & 0 & 0 & 3 & 18 \\
Patent1 & 13410 & 2.521 & 8.849 & 0 & 0 & 0 & 1 & 6 \\
Patent23 & 13410 & 5.212 & 18.492 & 0 & 0 & 0 & 1 & 11 \\
FPG & 13410 & 4.579 & 3.950 & 1.163 & 2.050 & 3.484 & 5.769 & 9.121 \\
SOE & 13410 & 0.664 & 0.472 & 0 & 0 & 1 & 1 & 1 \\
Assets(billion) & 13410 & 5.473 & 11.446 & 0.650 & 1.095 & 2.132 & 4.569 & 10.786 \\
Size & 13410 & 21.605 & 1.142 & 20.292 & 20.814 & 21.480 & 22.242 & 23.102 \\
Leverage & 13410 & 0.497 & 0.193 & 0.228 & 0.362 & 0.507 & 0.638 & 0.741 \\
ROA & 13410 & 0.030 & 0.059 & -0.011 & 0.010 & 0.030 & 0.056 & 0.090 \\
Tangibility & 13410 & 0.302 & 0.195 & 0.065 & 0.151 & 0.269 & 0.434 & 0.584 \\
Age & 13410 & 12.762 & 4.718 & 6 & 9 & 12 & 16 & 19 \\
SalesGrowth & 13410 & 0.243 & 0.645 & -0.188 & -0.013 & 0.140 & 0.323 & 0.600 \\
HHI & 13410 & 0.067 & 0.060 & 0.024 & 0.033 & 0.046 & 0.078 & 0.140 \\
Dual & 13410 & 0.141 & 0.348 & 0 & 0 & 0 & 0 & 1 \\
IndRatio & 13410 & 0.339 & 0.085 & 0.273 & 0.333 & 0.333 & 0.364 & 0.429 \\
MH(\%) & 13410 & 2.408 & 9.706 & 0 & 0 & 0.004 & 0.033 & 0.609 \\
TMP(\%) & 13410 & 0.280 & 0.510 & 0.030 & 0.067 & 0.146 & 0.303 & 0.600 \\
\hline
\end{tabular}




\section{Table 2 Baseline Regression of Firm Innovation on Firm Pay Gap}

This table reports the regressions of innovation outcome variables (one-year-ahead total innovation outputs, innovation quality and innovation quantity) on firm pay gap and other control variables. Definitions of variables are listed in Panel A of Table 1. T-statistics are displayed in parentheses. ***, ** and * indicate significance at $1 \%, 5 \%$ and $10 \%$ respectively.

\begin{tabular}{|c|c|c|c|}
\hline \multirow[b]{2}{*}{ Variable } & LnPatent $_{t+1}$ & LnPatent $_{t+1}$ & LnPatent $23_{t+1}$ \\
\hline & Reg-1 & Reg-2 & Reg-3 \\
\hline \multirow[t]{2}{*}{$F P G$} & $0.023 * * *$ & $0.013^{*}$ & $0.026 * * *$ \\
\hline & $(2.980)$ & $(1.815)$ & $(3.078)$ \\
\hline \multirow[t]{2}{*}{$S O E$} & $0.144 * *$ & $0.149 * *$ & 0.028 \\
\hline & $(1.985)$ & $(2.157)$ & $(0.355)$ \\
\hline \multirow[t]{2}{*}{ Size } & $0.770 * * *$ & $0.710 * * *$ & $0.745 * * *$ \\
\hline & $(21.218)$ & $(20.613)$ & (18.904) \\
\hline \multirow[t]{2}{*}{ Leverage } & $-1.037 * * *$ & $-0.784 * * *$ & $-0.814 * * *$ \\
\hline & $(-5.312)$ & $(-4.193)$ & $(-3.798)$ \\
\hline \multirow[t]{2}{*}{$R O A$} & $4.713 * * *$ & $4.549 * * *$ & $4.177 * * *$ \\
\hline & $(7.383)$ & $(7.488)$ & $(5.893)$ \\
\hline \multirow[t]{2}{*}{ Tangibility } & 0.213 & 0.247 & 0.079 \\
\hline & (1.028) & $(1.249)$ & $(0.344)$ \\
\hline \multirow[t]{2}{*}{ Age } & $-0.052 * * *$ & $-0.060 * * *$ & $-0.031 * * *$ \\
\hline & $(-6.016)$ & $(-7.164)$ & $(-3.348)$ \\
\hline \multirow[t]{2}{*}{ SalesGrowth } & $-0.196 * * *$ & $-0.163 * * *$ & $-0.154 * *$ \\
\hline & $(-3.099)$ & $(-2.816)$ & $(-2.341)$ \\
\hline \multirow[t]{2}{*}{$H H I$} & 1.054 & 1.462 & 0.247 \\
\hline & $(0.738)$ & $(1.061)$ & $(0.162)$ \\
\hline \multirow[t]{2}{*}{ Dual } & $0.254 * * *$ & $0.341 * * *$ & 0.125 \\
\hline & $(2.960)$ & $(4.294)$ & $(1.272)$ \\
\hline \multirow[t]{2}{*}{ IndRatio } & $1.036^{*}$ & $0.956^{*}$ & $1.071^{*}$ \\
\hline & $(1.926)$ & $(1.852)$ & $(1.829)$ \\
\hline \multirow[t]{2}{*}{$M H$} & $0.015 * * *$ & $0.009^{* *}$ & $0.014 * * *$ \\
\hline & $(3.871)$ & $(2.431)$ & $(3.242)$ \\
\hline \multirow[t]{2}{*}{$T M P$} & $-0.493 * * *$ & $-0.240 * *$ & $-0.786^{* * *}$ \\
\hline & $(-4.458)$ & $(-2.530)$ & $(-5.321)$ \\
\hline Industry Effect & YES & YES & YES \\
\hline Year Effect & YES & YES & YES \\
\hline \multirow[t]{2}{*}{ Constant } & $-19.046^{* * *}$ & $-18.361 * * *$ & $-19.413 * * *$ \\
\hline & $(-22.354)$ & $(-22.176)$ & $(-20.150)$ \\
\hline Obs & 10,790 & 10,790 & 10,790 \\
\hline
\end{tabular}




\section{Table 3 Non-linear Model Regression.}

This table reports the nonlinear model regressions of innovation outcome variables (one-year-ahead total innovation outputs, innovation quality and innovation quantity) on firm pay gap and other control variables. In this model, we introduce the quadratic item of pay gap $\left(F P G^{2}\right)$ to examine the trade-off between the tournament theory and the comparison theories about the real effects of pay gap. Definitions of variables are listed in Panel A of Table 1. T-statistics are displayed in parentheses. ***,** and * indicate significance at $1 \%$, $5 \%$ and $10 \%$ respectively.

\begin{tabular}{|c|c|c|c|}
\hline & LnPatent $_{t+1}$ & LnPatent $_{t+1}$ & LnPatent $23_{t+1}$ \\
\hline Variable & Reg-1 & Reg-2 & Reg-3 \\
\hline \multirow[t]{2}{*}{$F P G$} & $0.070 * * *$ & $0.045^{* *}$ & $0.071 * * *$ \\
\hline & (3.397) & $(2.338)$ & $(3.135)$ \\
\hline \multirow[t]{2}{*}{$F P G^{2}$} & $-0.003 * *$ & $-0.002 *$ & $-0.002 * *$ \\
\hline & $(-2.420)$ & $(-1.765)$ & $(-2.113)$ \\
\hline \multirow[t]{2}{*}{$S O E$} & $0.151 * *$ & $0.154 * *$ & 0.035 \\
\hline & $(2.085)$ & $(2.239)$ & $(0.440)$ \\
\hline \multirow[t]{2}{*}{ Size } & $0.769 * * *$ & $0.709 * * *$ & $0.744 * * *$ \\
\hline & $(21.185)$ & $(20.586)$ & $(18.855)$ \\
\hline \multirow[t]{2}{*}{ Leverage } & $-1.040 * * *$ & $-0.787 * * *$ & $-0.816 * * *$ \\
\hline & $(-5.334)$ & $(-4.206)$ & $(-3.812)$ \\
\hline \multirow[t]{2}{*}{$R O A$} & $4.612 * * *$ & $4.477 * * *$ & $4.078 * * *$ \\
\hline & $(7.205)$ & $(7.345)$ & $(5.737)$ \\
\hline \multirow[t]{2}{*}{ Tangibility } & 0.195 & 0.233 & 0.060 \\
\hline & $(0.940)$ & (1.179) & $(0.260)$ \\
\hline \multirow[t]{2}{*}{ Age } & $-0.051^{* * *}$ & $-0.059 * * *$ & $-0.030 * * *$ \\
\hline & $(-5.858)$ & $(-7.045)$ & $(-3.204)$ \\
\hline \multirow[t]{2}{*}{ SalesGrowth } & $-0.196 * * *$ & $-0.163 * * *$ & $-0.154 * *$ \\
\hline & $(-3.102)$ & $(-2.817)$ & $(-2.344)$ \\
\hline \multirow[t]{2}{*}{$H H I$} & 1.081 & 1.474 & 0.275 \\
\hline & $(0.758)$ & $(1.071)$ & $(0.181)$ \\
\hline \multirow[t]{2}{*}{ Dual } & $0.259 * * *$ & $0.344 * * *$ & 0.131 \\
\hline & $(3.025)$ & $(4.335)$ & (1.332) \\
\hline \multirow[t]{2}{*}{ IndRatio } & $1.055^{* *}$ & $0.966^{*}$ & $1.087^{*}$ \\
\hline & $(1.963)$ & (1.874) & $(1.859)$ \\
\hline \multirow[t]{2}{*}{$M H$} & $0.015 * * *$ & $0.009 * *$ & $0.013 * * *$ \\
\hline & $(3.832)$ & $(2.404)$ & $(3.214)$ \\
\hline \multirow[t]{2}{*}{$T M P$} & $-0.503^{* * *}$ & $-0.245 * *$ & $-0.801 * * *$ \\
\hline & $(-4.491)$ & $(-2.549)$ & $(-5.345)$ \\
\hline Industry Effect & YES & YES & YES \\
\hline Year Effect & YES & YES & YES \\
\hline \multirow[t]{2}{*}{ Constant } & $-19.113 * * *$ & $-18.404 * * *$ & $-19.471 * * *$ \\
\hline & $(-22.422)$ & $(-22.213)$ & $(-20.193)$ \\
\hline Obs & 10,790 & 10,790 & 10,790 \\
\hline
\end{tabular}




\section{Table 4 Comparative Results of Small and Large Pay Gap Group.}

This table reports the comparative results of small and large pay gap group based on the baseline model regressions of innovation outcome variables (one-year-ahead total innovation outputs, innovation quality and innovation quantity) on firm pay gap and other control variables. The whole sample is divided into three subsamples with nearly equal quantity of observations according to the industry-year pay gap rank. group $=1$ and group $=3$ denotes subsample of low and high pay gap respectively. Definitions of variables are listed in Panel A of Table 1. T-statistics are displayed in parentheses. ***,** and * indicate significance at $1 \%, 5 \%$ and $10 \%$ respectively.

\begin{tabular}{|c|c|c|c|c|c|c|}
\hline \multirow[b]{3}{*}{ Variable } & \multicolumn{2}{|c|}{ LnPatent $_{t+1}$} & \multicolumn{2}{|c|}{ LnPatent $_{t+1}$} & \multicolumn{2}{|c|}{ LnPatent $23_{t+1}$} \\
\hline & Reg-1 & Reg-2 & Reg-3 & Reg-4 & Reg-5 & Reg-6 \\
\hline & group $=1$ & group $=3$ & group $=1$ & group $=3$ & group $=1$ & group $=3$ \\
\hline \multirow{2}{*}{$F P G$} & $0.333 * * *$ & -0.006 & $0.252 * * *$ & -0.010 & $0.352 * * *$ & 0.000 \\
\hline & $(4.496)$ & $(-0.486)$ & $(3.652)$ & $(-0.882)$ & $(4.331)$ & $(0.017)$ \\
\hline \multirow[t]{2}{*}{$S O E$} & $0.262 * *$ & -0.033 & $0.299 * *$ & -0.093 & 0.117 & -0.096 \\
\hline & $(1.985)$ & $(-0.287)$ & $(2.411)$ & $(-0.879)$ & $(0.805)$ & $(-0.759)$ \\
\hline \multirow[t]{2}{*}{ Size } & $0.664 * * *$ & $0.792 * * *$ & $0.559 * * *$ & $0.751 * * *$ & $0.672 * * *$ & $0.763 * * *$ \\
\hline & (10.611) & (12.202) & $(9.648)$ & $(12.265)$ & $(9.836)$ & (10.976) \\
\hline \multirow[t]{2}{*}{ Leverage } & $-0.766 * *$ & $-0.897 * *$ & $-0.800 * * *$ & -0.438 & -0.387 & $-0.969 * *$ \\
\hline & $(-2.444)$ & $(-2.465)$ & $(-2.670)$ & $(-1.298)$ & $(-1.130)$ & $(-2.438)$ \\
\hline \multirow[t]{2}{*}{$R O A$} & $4.212 * * *$ & $5.493 * * *$ & $4.069 * * *$ & $5.077 * * *$ & $4.331 * * *$ & $3.653 * * *$ \\
\hline & $(4.041)$ & $(4.935)$ & $(4.091)$ & $(4.810)$ & $(3.701)$ & $(2.980)$ \\
\hline \multirow[t]{2}{*}{ Tangibility } & $0.769^{* *}$ & 0.315 & 0.498 & 0.258 & $0.769^{* *}$ & -0.062 \\
\hline & $(2.197)$ & $(0.898)$ & $(1.464)$ & $(0.799)$ & (1.997) & $(-0.159)$ \\
\hline \multirow[t]{2}{*}{ Age } & $-0.036 * *$ & $-0.054 * * *$ & $-0.053 * * *$ & $-0.054 * * *$ & -0.017 & $-0.028^{*}$ \\
\hline & $(-2.272)$ & $(-3.780)$ & $(-3.410)$ & $(-3.969)$ & $(-0.972)$ & $(-1.791)$ \\
\hline \multirow[t]{2}{*}{ SalesGrowth } & $-0.368 * * *$ & -0.047 & $-0.261 * * *$ & -0.002 & $-0.315 * * *$ & 0.010 \\
\hline & $(-3.340)$ & $(-0.500)$ & $(-2.719)$ & $(-0.021)$ & $(-2.739)$ & (0.106) \\
\hline \multirow[t]{2}{*}{$H H I$} & -1.597 & -0.424 & -2.008 & 1.195 & -1.685 & -1.612 \\
\hline & $(-0.620)$ & $(-0.182)$ & $(-0.857)$ & $(0.540)$ & $(-0.604)$ & $(-0.653)$ \\
\hline \multirow[t]{2}{*}{ Dual } & -0.032 & $0.536 * * *$ & 0.133 & $0.592 * * *$ & -0.109 & $0.299 *$ \\
\hline & $(-0.197)$ & $(3.920)$ & (0.908) & $(4.822)$ & $(-0.590)$ & (1.854) \\
\hline \multirow[t]{2}{*}{ IndRatio } & $2.045^{* *}$ & 0.703 & 0.987 & $1.476^{*}$ & $1.974 * *$ & 0.049 \\
\hline & $(2.264)$ & $(0.773)$ & (1.182) & $(1.742)$ & $(1.979)$ & $(0.049)$ \\
\hline \multirow[t]{2}{*}{$M H$} & $0.029 * * *$ & $0.011 *$ & $0.015^{* *}$ & $0.011 * *$ & $0.029 * * *$ & 0.008 \\
\hline & (3.971) & $(1.894)$ & $(2.141)$ & $(2.010)$ & $(3.703)$ & $(1.241)$ \\
\hline \multirow[t]{2}{*}{$T M P$} & $-0.821 * * *$ & $-0.495^{* *}$ & $-0.410^{* *}$ & $-0.352 * *$ & $-1.225^{* * *}$ & $-0.675^{* * *}$ \\
\hline & $(-3.553)$ & $(-2.509)$ & $(-2.210)$ & $(-2.005)$ & $(-4.284)$ & $(-2.664)$ \\
\hline Industry Effect & YES & YES & YES & YES & YES & YES \\
\hline Year Effect & YES & YES & YES & YES & YES & YES \\
\hline \multirow[t]{2}{*}{ Constant } & $-16.919 * * *$ & $-19.529 * * *$ & $-14.872 * * *$ & $-19.867 * * *$ & $-18.218 * * *$ & $-19.392 * * *$ \\
\hline & $(-11.138)$ & $(-13.131)$ & $(-10.800)$ & $(-13.245)$ & $(-10.328)$ & $(-12.013)$ \\
\hline Obs & 3,686 & 3,581 & 3,686 & 3,581 & 3,686 & 3,581 \\
\hline
\end{tabular}


Table 5 Two-Stage Least-Squares Regression with the Instrument Variable of Provincial Minimum Wage.

This table reports the two-stage least-squares regressions of innovation outcome variables (one-year-ahead total innovation outputs, innovation quality and innovation quantity on firm pay gap and other control variables, with the provincial minimum wage as the instrument variable. The first column reports the first stage result of the 2SLS regression. Year effect was not included because the trend of minimum wage was monotonically non-decreasing. $F$-statistic is a test statistic for instrument variable. The last three columns report the second stage results of the 2SLS regression. Definitions of variables are listed in Panel A of Table 1. T-statistics are displayed in parentheses. $* * *, * *$ and $*$ indicate significance at $1 \%, 5 \%$ and $10 \%$ respectively.

\begin{tabular}{|c|c|c|c|c|}
\hline \multirow[b]{3}{*}{ Variable } & \multirow{2}{*}{$\begin{array}{c}\text { First Stage } \\
F P G \\
\end{array}$} & \multicolumn{3}{|c|}{ Second Stage } \\
\hline & & LnPatent $_{t+1}$ & LnPatent $_{t+1}$ & LnPatent $23_{t+1}$ \\
\hline & Reg-1 & Reg-2 & Reg-3 & Reg-4 \\
\hline Minwage & $\begin{array}{c}-0.929 * * * \\
(-6.375)\end{array}$ & & & \\
\hline$F P G$ & & $\begin{array}{c}0.579 * * * \\
(2.739)\end{array}$ & $\begin{array}{c}0.504 * * * \\
(2.816)\end{array}$ & $\begin{array}{c}0.257 * * \\
(2.126)\end{array}$ \\
\hline$S O E$ & $\begin{array}{c}-0.922 * * * \\
(-11.051)\end{array}$ & $\begin{array}{c}0.531 \text { *** } \\
(2.681)\end{array}$ & $\begin{array}{c}0.460 * * * \\
(2.751)\end{array}$ & $\begin{array}{l}0.219^{*} \\
(1.950)\end{array}$ \\
\hline Size & $\begin{array}{c}0.941 * * * \\
(21.372)\end{array}$ & $\begin{array}{c}-0.216 \\
(-1.066)\end{array}$ & $\begin{array}{c}-0.242 \\
(-1.413)\end{array}$ & $\begin{array}{c}0.031 \\
(0.267)\end{array}$ \\
\hline Leverage & $\begin{array}{c}0.636 * * * \\
(3.137)\end{array}$ & $\begin{array}{c}-0.691 * * * \\
(-3.432)\end{array}$ & $\begin{array}{c}-0.528 * * * \\
(-3.084)\end{array}$ & $\begin{array}{c}-0.369^{* * *} \\
(-3.327)\end{array}$ \\
\hline$R O A$ & $\begin{array}{c}6.530 * * * \\
(9.328)\end{array}$ & $\begin{array}{c}-2.215 \\
(-1.450)\end{array}$ & $\begin{array}{l}-2.338^{*} \\
(-1.808)\end{array}$ & $\begin{array}{c}-0.537 \\
(-0.623)\end{array}$ \\
\hline Tangibility & $\begin{array}{l}0.395^{*} \\
(1.946)\end{array}$ & $\begin{array}{c}-0.247 \\
(-1.299)\end{array}$ & $\begin{array}{c}-0.221 \\
(-1.378)\end{array}$ & $\begin{array}{c}-0.122 \\
(-1.136)\end{array}$ \\
\hline Age & $\begin{array}{c}0.027 * * * \\
(2.970)\end{array}$ & $\begin{array}{c}-0.047 * * * \\
(-3.412)\end{array}$ & $\begin{array}{c}-0.042 * * * \\
(-3.575)\end{array}$ & $\begin{array}{c}-0.020^{* *} \\
(-2.523)\end{array}$ \\
\hline SalesGrowth & $\begin{array}{l}-0.105^{*} \\
(-1.825)\end{array}$ & $\begin{array}{c}-0.009 \\
(-0.229)\end{array}$ & $\begin{array}{c}0.001 \\
(0.041)\end{array}$ & $\begin{array}{c}-0.012 \\
(-0.542)\end{array}$ \\
\hline$H H I$ & $\begin{array}{c}0.443 \\
(0.287)\end{array}$ & $\begin{array}{c}1.454 \\
(1.180)\end{array}$ & $\begin{array}{c}1.462 \\
(1.406)\end{array}$ & $\begin{array}{l}1.246^{*} \\
(1.720)\end{array}$ \\
\hline Dual & $\begin{array}{c}0.289 * * * \\
(2.879)\end{array}$ & $\begin{array}{c}-0.073 \\
(-0.642)\end{array}$ & $\begin{array}{c}-0.068 \\
(-0.716)\end{array}$ & $\begin{array}{c}-0.011 \\
(-0.170)\end{array}$ \\
\hline IndRatio & $\begin{array}{c}0.877 * * \\
(2.203)\end{array}$ & $\begin{array}{c}0.279 \\
(0.683)\end{array}$ & $\begin{array}{c}0.154 \\
(0.450)\end{array}$ & $\begin{array}{c}0.327 \\
(1.371)\end{array}$ \\
\hline$M H$ & $\begin{array}{c}-0.000 \\
(-0.093)\end{array}$ & $\begin{array}{c}0.005 \\
(1.578)\end{array}$ & $\begin{array}{c}0.002 \\
(0.708)\end{array}$ & $\begin{array}{c}0.005^{* *} \\
(2.038)\end{array}$ \\
\hline$T M P$ & $\begin{array}{c}0.901 * * * \\
(7.070)\end{array}$ & $\begin{array}{c}-0.572 * * \\
(-2.416)\end{array}$ & $\begin{array}{c}-0.469 * * \\
(-2.351)\end{array}$ & $\begin{array}{c}-0.269 * * \\
(-2.064)\end{array}$ \\
\hline Industry Effect & YES & YES & YES & YES \\
\hline Year Effect & NO & YES & YES & YES \\
\hline Constant & $\begin{array}{c}-15.171 * * * \\
(-16.020)\end{array}$ & $\begin{array}{c}2.733 \\
(0.754)\end{array}$ & $\begin{array}{c}3.482 \\
(1.136)\end{array}$ & $\begin{array}{c}-1.516 \\
(-0.730)\end{array}$ \\
\hline Obs & 13,410 & 10,790 & 10,790 & 10,790 \\
\hline$F$-statistics & $40.64 * * *$ & & & \\
\hline
\end{tabular}




\section{Table 6 Alternative Proxy for Innovation.}

This table reports the effect of firm pay gap on innovation using an alternative proxy, R\&D expenditure, for innovation. $\operatorname{Ln}(R \& D)$ denotes the natural logarithm of the R\&D expenditure. Definitions of variables are listed in Panel A of Table 1. T-statistics are displayed in parentheses. ***, ** and * indicate significance at 1\%, 5\% and $10 \%$ respectively.

\begin{tabular}{|c|c|c|}
\hline \multirow[b]{2}{*}{ Variable } & $\operatorname{Ln}(R \& D)_{t}$ & $\operatorname{Ln}(R \& D)_{t}$ \\
\hline & Reg-1 & Reg-2 \\
\hline \multirow[t]{2}{*}{$F P G$} & $0.092 * * *$ & $0.022 * * *$ \\
\hline & (11.954) & $(3.262)$ \\
\hline \multirow[t]{2}{*}{$S O E$} & & -0.017 \\
\hline & & $(-0.309)$ \\
\hline \multirow[t]{2}{*}{ Size } & & $0.901 * * *$ \\
\hline & & $(32.224)$ \\
\hline \multirow[t]{2}{*}{ Leverage } & & $-0.792 * * *$ \\
\hline & & $(-5.477)$ \\
\hline \multirow[t]{2}{*}{$R O A$} & & $4.180 * * *$ \\
\hline & & (8.389) \\
\hline \multirow[t]{2}{*}{ Tangibility } & & 0.049 \\
\hline & & $(0.265)$ \\
\hline \multirow[t]{2}{*}{ Age } & & $-0.038 * * *$ \\
\hline & & $(-7.802)$ \\
\hline \multirow[t]{2}{*}{ SalesGrowth } & & -0.025 \\
\hline & & $(-0.493)$ \\
\hline \multirow[t]{2}{*}{$H H I$} & & -1.212 \\
\hline & & $(-0.839)$ \\
\hline \multirow[t]{2}{*}{ Dual } & & $0.169 * * *$ \\
\hline & & $(3.144)$ \\
\hline \multirow[t]{2}{*}{ IndRatio } & & -0.555 \\
\hline & & $(-1.312)$ \\
\hline \multirow[t]{2}{*}{$M H$} & & $0.003 * *$ \\
\hline & & $(2.325)$ \\
\hline \multirow[t]{2}{*}{$T M P$} & & $-0.205^{* * *}$ \\
\hline & & $(-2.835)$ \\
\hline Industry Effect & YES & YES \\
\hline Year Effect & YES & YES \\
\hline \multirow[t]{2}{*}{ Constant } & $15.354 * * *$ & $-2.948 * * *$ \\
\hline & $(65.503)$ & $(-4.581)$ \\
\hline$O b s$ & 3,848 & 3,848 \\
\hline
\end{tabular}




\section{Table 7 Robustness Test: Technology-Intensive Industries.}

This table reports the effects of firm pay gap in technology-intensive industries. Hi-Tech denotes subsample of firms in technology-intensive industries. Definitions of variables are listed in Panel A of Table 1. T-statistics are displayed in parentheses. $* * *, * *$ and $*$ indicate significance at $1 \%, 5 \%$ and $10 \%$ respectively.

\begin{tabular}{|c|c|c|c|}
\hline & LnPatent $_{t+1}$ & LnPatent $_{t+1}$ & LnPatent $23_{t+1}$ \\
\hline & Reg-1 & Reg-2 & Reg-3 \\
\hline Variable & Hi-Tech & Hi-Tech & Hi-Tech \\
\hline$F P G$ & $0.042 * * *$ & $0.024 * *$ & $0.046 * * *$ \\
\hline & $(3.876)$ & $(2.444)$ & $(4.000)$ \\
\hline$S O E$ & $0.342 * * *$ & $0.239 * * *$ & $0.341 * * *$ \\
\hline & $(3.651)$ & $(2.651)$ & $(3.385)$ \\
\hline Size & $0.813 * * *$ & $0.807 * * *$ & $0.696 * * *$ \\
\hline & (15.098) & $(15.864)$ & $(12.546)$ \\
\hline Leverage & $-1.237 * * *$ & $-0.784 * * *$ & $-0.864 * * *$ \\
\hline & $(-4.649)$ & $(-3.049)$ & $(-3.088)$ \\
\hline$R O A$ & $4.876^{* * *}$ & $4.475 * * *$ & $4.637 * * *$ \\
\hline & $(5.717)$ & $(5.337)$ & (5.116) \\
\hline Tangibility & $0.560^{*}$ & 0.482 & 0.087 \\
\hline & $(1.650)$ & $(1.456)$ & $(0.244)$ \\
\hline Age & $-0.072 * * *$ & $-0.079 * * *$ & $-0.050 * * *$ \\
\hline & $(-6.408)$ & $(-7.056)$ & $(-4.269)$ \\
\hline SalesGrowth & $-0.198 * *$ & $-0.160 * *$ & $-0.173^{*}$ \\
\hline & $(-2.173)$ & $(-2.017)$ & $(-1.912)$ \\
\hline$H H I$ & 1.753 & 1.705 & 0.575 \\
\hline & $(0.926)$ & $(0.952)$ & $(0.288)$ \\
\hline Dual & $0.231 * *$ & $0.256^{* *}$ & 0.103 \\
\hline & $(2.040)$ & $(2.474)$ & $(0.812)$ \\
\hline IndRatio & -0.428 & -0.383 & -0.100 \\
\hline & $(-0.591)$ & $(-0.557)$ & $(-0.131)$ \\
\hline$M H$ & $0.012 * *$ & 0.007 & $0.013^{* *}$ \\
\hline & $(2.352)$ & (1.563) & (2.409) \\
\hline$T M P$ & $-0.333 * *$ & 0.033 & $-0.836^{* * *}$ \\
\hline & $(-2.395)$ & $(0.307)$ & $(-4.388)$ \\
\hline Industry Effect & YES & YES & YES \\
\hline Year Effect & YES & YES & YES \\
\hline Constant & $-18.023 * * *$ & $-19.327 * * *$ & $-16.323 * * *$ \\
\hline & $(-14.808)$ & $(-16.120)$ & $(-12.645)$ \\
\hline Obs & 3,712 & 3,712 & 3,712 \\
\hline
\end{tabular}


Table 8 Robustness Test: Effects of "The Minimum Wage Regulations".

This table reports the two-stage least-squares regressions of innovation outcome variables (one-year-ahead total innovation outputs, innovation quality and innovation quantity) on firm pay gap and other control variables using the post-2004 subsample. The first two columns report the first stage result of the 2SLS regression in pre- and post-2004 subsamples respectively. Year effect was not included because the trend of minimum wage was monotonically non-decreasing. $F$-statistic is a test statistic for instrument variable. The last three columns report the second stage results of the 2SLS regression. Definitions of variables are listed in Panel A of Table 1. T-statistics are displayed in parentheses. $* * *, * *$ and $*$ indicate significance at $1 \%, 5 \%$ and $10 \%$ respectively.

\begin{tabular}{|c|c|c|c|c|c|}
\hline \multirow{3}{*}{ Variables } & \multicolumn{2}{|c|}{ First Stage } & \multicolumn{3}{|c|}{ Second Stage } \\
\hline & $F P G$ & $F P G$ & LnPatent $_{t+1}$ & LnPatent $_{t+1}$ & LnPatent $23_{t+1}$ \\
\hline & $\begin{array}{c}\text { Reg-1 } \\
\text { (Pre-2004) }\end{array}$ & $\begin{array}{c}\text { Reg-2 } \\
\text { (Post-2004) }\end{array}$ & $\begin{array}{c}\text { Reg-3 } \\
\text { (Post-2004) }\end{array}$ & $\begin{array}{c}\text { Reg-4 } \\
\text { (Post-2004) }\end{array}$ & $\begin{array}{c}\text { Reg-5 } \\
\text { (Post-2004) }\end{array}$ \\
\hline Minwage & $\begin{array}{c}-0.558 \\
(-0.618)\end{array}$ & $\begin{array}{c}-0.917 * * * \\
(-5.929)\end{array}$ & & & \\
\hline$F P G$ & & & $\begin{array}{c}0.474 * * * \\
(2.800)\end{array}$ & $\begin{array}{c}0.437 * * * \\
(2.952)\end{array}$ & $\begin{array}{l}0.190^{*} \\
(1.880)\end{array}$ \\
\hline$S O E$ & $\begin{array}{c}-1.022 * * * \\
(-4.062)\end{array}$ & $\begin{array}{c}-0.916 * * * \\
(-10.419)\end{array}$ & $\begin{array}{c}0.433 * * * \\
(2.815)\end{array}$ & $\begin{array}{c}0.390^{* * *} \\
(2.901)\end{array}$ & $\begin{array}{l}0.166^{*} \\
(1.817)\end{array}$ \\
\hline Size & $\begin{array}{c}0.840 * * * \\
(6.372)\end{array}$ & $\begin{array}{c}0.963 * * * \\
(20.863)\end{array}$ & $\begin{array}{c}-0.118 \\
(-0.714)\end{array}$ & $\begin{array}{c}-0.176 \\
(-1.213)\end{array}$ & $\begin{array}{c}0.096 \\
(0.963)\end{array}$ \\
\hline Leverage & $\begin{array}{c}0.316 \\
(0.500)\end{array}$ & $\begin{array}{c}0.692 * * * \\
(3.304)\end{array}$ & $\begin{array}{c}-0.703 * * * \\
(-3.855)\end{array}$ & $\begin{array}{c}-0.565^{* * * *} \\
(-3.519)\end{array}$ & $\begin{array}{c}-0.356 * * * \\
(-3.330)\end{array}$ \\
\hline$R O A$ & $\begin{array}{c}2.258 \\
(1.206)\end{array}$ & $\begin{array}{l}7.568 * * * \\
(10.192)\end{array}$ & $\begin{array}{c}-1.873 \\
(-1.293)\end{array}$ & $\begin{array}{l}-2.319^{*} \\
(-1.829)\end{array}$ & $\begin{array}{c}-0.123 \\
(-0.143)\end{array}$ \\
\hline Tangibility & $\begin{array}{c}0.602 \\
(1.125)\end{array}$ & $\begin{array}{l}0.386^{*} \\
(1.738)\end{array}$ & $\begin{array}{c}-0.229 \\
(-1.288)\end{array}$ & $\begin{array}{c}-0.221 \\
(-1.426)\end{array}$ & $\begin{array}{c}-0.104 \\
(-0.997)\end{array}$ \\
\hline Age & $\begin{array}{c}0.015 \\
(0.587)\end{array}$ & $\begin{array}{c}0.029 * * * \\
(2.917)\end{array}$ & $\begin{array}{c}-0.047 * * * \\
(-3.814)\end{array}$ & $\begin{array}{c}-0.041 * * * \\
(-3.830)\end{array}$ & $\begin{array}{c}-0.020 * * * \\
(-2.700)\end{array}$ \\
\hline SalesGrowth & $\begin{array}{c}0.087 \\
(0.640)\end{array}$ & $\begin{array}{c}-0.125 * * \\
(-1.980)\end{array}$ & $\begin{array}{c}-0.022 \\
(-0.585)\end{array}$ & $\begin{array}{c}-0.003 \\
(-0.080)\end{array}$ & $\begin{array}{c}-0.023 \\
(-1.083)\end{array}$ \\
\hline$H H I$ & $\begin{array}{c}-0.573 \\
(-0.134)\end{array}$ & $\begin{array}{c}-0.065 \\
(-0.036)\end{array}$ & $\begin{array}{c}1.162 \\
(0.893)\end{array}$ & $\begin{array}{c}1.504 \\
(1.328)\end{array}$ & $\begin{array}{c}0.738 \\
(0.916)\end{array}$ \\
\hline Dual & $\begin{array}{c}0.634 * * \\
(2.214)\end{array}$ & $\begin{array}{c}0.237 * * \\
(2.221)\end{array}$ & $\begin{array}{c}0.012 \\
(0.138)\end{array}$ & $\begin{array}{c}-0.001 \\
(-0.007)\end{array}$ & $\begin{array}{c}0.029 \\
(0.554)\end{array}$ \\
\hline IndRatio & $\begin{array}{c}1.885^{* * *} \\
(3.116)\end{array}$ & $\begin{array}{c}-0.597 \\
(-0.863)\end{array}$ & $\begin{array}{l}0.820^{*} \\
(1.782)\end{array}$ & $\begin{array}{l}0.683^{*} \\
(1.716)\end{array}$ & $\begin{array}{c}0.645^{* *} \\
(2.214)\end{array}$ \\
\hline$M H$ & $\begin{array}{c}-0.023 \\
(-0.730)\end{array}$ & $\begin{array}{c}0.001 \\
(0.196)\end{array}$ & $\begin{array}{c}0.004 \\
(1.248)\end{array}$ & $\begin{array}{c}0.001 \\
(0.337)\end{array}$ & $\begin{array}{l}0.004 * \\
(1.765)\end{array}$ \\
\hline$T M P$ & $\begin{array}{c}3.137 * * * \\
(5.542)\end{array}$ & $\begin{array}{c}0.746 * * * \\
(6.431)\end{array}$ & $\begin{array}{c}-0.377 * * \\
(-2.391)\end{array}$ & $\begin{array}{c}-0.320 * * \\
(-2.324)\end{array}$ & $\begin{array}{l}-0.165^{*} \\
(-1.862)\end{array}$ \\
\hline Industry Effect & YES & YES & YES & YES & YES \\
\hline Year Effect & NO & NO & YES & YES & YES \\
\hline Constant & $\begin{array}{c}-12.496 * * * \\
(-4.404)\end{array}$ & $\begin{array}{c}-15.327 * * * \\
(-15.131)\end{array}$ & $\begin{array}{c}1.481 \\
(0.499)\end{array}$ & $\begin{array}{c}2.595 \\
(1.000)\end{array}$ & $\begin{array}{c}-2.339 \\
(-1.310)\end{array}$ \\
\hline Obs & 2,244 & 11,166 & 8,720 & 8,720 & 8,720 \\
\hline$F$-statistics & 0.38 & $35.16^{* * * *}$ & & & \\
\hline
\end{tabular}




\section{Table 9 Possible Mechanism: Division of Pay Gap.}

This table reports the regressions of innovation outcome variables (one-year-ahead total innovation outputs, innovation quality and innovation quantity) on the division components of firm pay gap and other control variables. $M P P$ denotes management pay premium, calculated as the average management pay $(A M P)$ in a firm relative to its industry-year median value; EPP denotes employee pay premium, calculated as the average employee pay $(A E P)$ relative to its industry-year median value; IPP is industry pay gap, calculated as the ratio of the industry-year median of $A M P$ and industry-year median of $A E P$. Definitions of other variables are listed in Panel A of Table 1. T-statistics are displayed in parentheses. ***, ** and * indicate significance at 1\%, 5\% and $10 \%$ respectively.

\begin{tabular}{|c|c|c|c|}
\hline \multirow[t]{2}{*}{ Variables } & LnPatent $_{t+1}$ & LnPatent $_{t+1}$ & LnPatent $23_{t+1}$ \\
\hline & Reg-1 & Reg-2 & Reg-3 \\
\hline \multirow[t]{2}{*}{$M P P$} & $0.314 * * *$ & $0.303 * * *$ & $0.245 * * *$ \\
\hline & $(8.450)$ & $(8.808)$ & $(5.920)$ \\
\hline \multirow[t]{2}{*}{$E P P$} & $-0.033 * *$ & -0.011 & $-0.036 * *$ \\
\hline & $(-2.445)$ & $(-0.920)$ & $(-2.320)$ \\
\hline \multirow[t]{2}{*}{$I P G$} & 0.089 & $0.141 * *$ & 0.032 \\
\hline & (1.254) & $(2.077)$ & $(0.406)$ \\
\hline \multirow[t]{2}{*}{$S O E$} & $0.124 *$ & $0.136^{* *}$ & 0.007 \\
\hline & (1.717) & (1.991) & $(0.091)$ \\
\hline \multirow[t]{2}{*}{ Size } & $0.654 * * *$ & $0.581 * * *$ & $0.665 * * *$ \\
\hline & $(16.311)$ & $(15.226)$ & (15.189) \\
\hline \multirow[t]{2}{*}{ Leverage } & $-1.054 * * *$ & $-0.824 * * *$ & $-0.819 * * *$ \\
\hline & $(-5.416)$ & $(-4.423)$ & $(-3.822)$ \\
\hline \multirow[t]{2}{*}{$R O A$} & $3.534 * * *$ & $3.180 * * *$ & $3.377 * * *$ \\
\hline & $(5.464)$ & $(5.245)$ & $(4.667)$ \\
\hline \multirow[t]{2}{*}{ Tangibility } & 0.234 & 0.282 & 0.089 \\
\hline & (1.132) & (1.430) & $(0.389)$ \\
\hline \multirow[t]{2}{*}{ Age } & $-0.052 * * *$ & $-0.060 * * *$ & $-0.030 * * *$ \\
\hline & $(-5.989)$ & $(-7.324)$ & $(-3.242)$ \\
\hline \multirow[t]{2}{*}{ SalesGrowth } & $-0.188 * * *$ & $-0.152 * * *$ & $-0.149 * *$ \\
\hline & $(-2.976)$ & $(-2.608)$ & $(-2.270)$ \\
\hline \multirow[t]{2}{*}{$H H I$} & 0.996 & 1.309 & 0.266 \\
\hline & $(0.693)$ & $(0.945)$ & $(0.174)$ \\
\hline \multirow[t]{2}{*}{ Dual } & $0.232 * * *$ & $0.316^{* * *}$ & 0.114 \\
\hline & $(2.709)$ & (3.984) & (1.158) \\
\hline \multirow[t]{2}{*}{ IndRatio } & $0.986^{*}$ & $0.881 *$ & $1.058^{*}$ \\
\hline & $(1.836)$ & $(1.710)$ & $(1.808)$ \\
\hline \multirow[t]{2}{*}{$M H$} & $0.015 * * *$ & $0.009^{* *}$ & $0.014 * * *$ \\
\hline & $(3.940)$ & $(2.495)$ & (3.306) \\
\hline \multirow[t]{2}{*}{$T M P$} & $-0.768 * * *$ & $-0.544 * * *$ & $-0.994 * * *$ \\
\hline & $(-5.772)$ & $(-4.311)$ & $(-5.975)$ \\
\hline Industry Effect & YES & YES & YES \\
\hline Year Effect & YES & YES & YES \\
\hline \multirow[t]{2}{*}{ Constant } & $-16.947 * * *$ & $-16.143^{* * *}$ & $-17.864 * * *$ \\
\hline & $(-18.395)$ & $(-18.105)$ & $(-17.186)$ \\
\hline Obs & 10,790 & 10,790 & 10,790 \\
\hline
\end{tabular}




\section{Table 10 Possible Mechanism: Human Capital.}

This table reports results on one possible mechanism through which management pay premium and employee pay premium affects firm innovation: human capital. Low HC denotes a subsample including observations that lie in the first tertile of industry-year human capital rank, and High HC in the top tertile. All denotes the whole sample. $M P P$ denotes management pay premium, calculated as the average management pay $(A M P)$ in a firm relative to its industry-year median value; $E P P$ denotes employee pay premium, calculated as the average employee pay $(A E P)$ relative to its industry-year median value; $I P P$ is industry pay gap, calculated as the ratio of the industry-year median of $A M P$ and industry-year median of $A E P$. $H C$ is an indicator variable that takes the value of one in the Low-HC subsample and zero otherwise. Definitions of other variables are listed in Panel A of Table 1. T-statistics are displayed in parentheses. ${ }^{* *}, * *$ and $*$ indicate significance at $1 \%, 5 \%$ and $10 \%$ respectively.

\begin{tabular}{|c|c|c|c|c|c|c|c|c|c|}
\hline \multirow[t]{3}{*}{ Variables } & \multicolumn{3}{|c|}{ LnPatent $_{t+1}$} & \multicolumn{3}{|c|}{ LnPatent $1_{t+1}$} & \multicolumn{3}{|c|}{ LnPatent $23_{t+1}$} \\
\hline & $\operatorname{Reg}-1$ & $\operatorname{Reg}-2$ & $\operatorname{Reg}-3$ & $\operatorname{Reg}-4$ & Reg-5 & Reg-6 & Reg-7 & $\operatorname{Reg}-8$ & $\operatorname{Reg}-9$ \\
\hline & Low HC & High HC & All & Low HC & High HC & All & Low HC & High $H C$ & All \\
\hline$M P P$ & $\begin{array}{c}0.250 * * * \\
(3.400)\end{array}$ & $\begin{array}{c}0.399 * * * \\
(6.785)\end{array}$ & $\begin{array}{c}0.313 * * * \\
(7.577)\end{array}$ & $\begin{array}{c}0.241 * * * \\
(3.668)\end{array}$ & $\begin{array}{c}0.309 * * * \\
(5.588)\end{array}$ & $\begin{array}{c}0.310 * * * \\
(8.137)\end{array}$ & $\begin{array}{c}0.175 * * \\
(2.199)\end{array}$ & $\begin{array}{c}0.384 * * * \\
(5.905)\end{array}$ & $\begin{array}{c}0.234 * * * \\
(5.052)\end{array}$ \\
\hline$E P P$ & $\begin{array}{c}-0.104 * * * \\
(-3.777)\end{array}$ & $\begin{array}{c}-0.025 \\
(-1.364)\end{array}$ & $\begin{array}{c}-0.018 \\
(-1.118)\end{array}$ & $\begin{array}{c}-0.073 * * * \\
(-2.825)\end{array}$ & $\begin{array}{c}-0.015 \\
(-0.930)\end{array}$ & $\begin{array}{c}0.002 \\
(0.117)\end{array}$ & $\begin{array}{c}-0.102 * * * \\
(-3.413)\end{array}$ & $\begin{array}{c}-0.018 \\
(-0.884)\end{array}$ & $\begin{array}{c}-0.021 \\
(-1.112)\end{array}$ \\
\hline$I P G$ & $\begin{array}{c}0.006 \\
(0.049)\end{array}$ & $\begin{array}{c}0.083 \\
(0.698)\end{array}$ & $\begin{array}{c}0.111 \\
(1.555)\end{array}$ & $\begin{array}{c}0.140 \\
(1.259)\end{array}$ & $\begin{array}{c}0.138 \\
(1.173)\end{array}$ & $\begin{array}{c}0.144 * * \\
(2.103)\end{array}$ & $\begin{array}{c}-0.139 \\
(-1.042)\end{array}$ & $\begin{array}{c}0.037 \\
(0.276)\end{array}$ & $\begin{array}{c}0.060 \\
(0.760)\end{array}$ \\
\hline$M P P^{*} H C$ & & & $\begin{array}{c}-0.004 \\
(-0.057)\end{array}$ & & & $\begin{array}{c}-0.080 \\
(-1.268)\end{array}$ & & & $\begin{array}{c}0.052 \\
(0.688)\end{array}$ \\
\hline$E P P * H C$ & & & $\begin{array}{l}-0.069 * * \\
(-2.215)\end{array}$ & & & $\begin{array}{l}-0.067 * * \\
(-2.366)\end{array}$ & & & $\begin{array}{l}-0.064 * \\
(-1.877)\end{array}$ \\
\hline$I P G^{*} H C$ & & & $\begin{array}{c}-0.029 \\
(-1.099)\end{array}$ & & & $\begin{array}{c}-0.016 \\
(-0.646)\end{array}$ & & & $\begin{array}{c}-0.021 \\
(-0.725)\end{array}$ \\
\hline Control Variables & YES & YES & YES & YES & YES & YES & YES & YES & YES \\
\hline Industry Effect & YES & YES & YES & YES & YES & YES & YES & YES & YES \\
\hline Year Effect & YES & YES & YES & YES & YES & YES & YES & YES & YES \\
\hline Constant & $\begin{array}{c}-19.026 * * * \\
(-11.339)\end{array}$ & $\begin{array}{c}-14.287 * * * \\
(-10.041)\end{array}$ & $\begin{array}{c}-16.700 * * * \\
(-18.004)\end{array}$ & $\begin{array}{c}-16.267 * * * \\
(-10.354)\end{array}$ & $\begin{array}{c}-14.839 * * * \\
(-10.540)\end{array}$ & $\begin{array}{c}-15.717 * * * \\
(-17.359)\end{array}$ & $\begin{array}{c}-20.156 * * * \\
(-10.750)\end{array}$ & $\begin{array}{c}-14.903 * * * \\
(-9.119)\end{array}$ & $\begin{array}{c}-17.659 * * * \\
(-16.981)\end{array}$ \\
\hline Obs & 3,607 & 3,542 & 10,615 & 3,607 & 3,542 & 10,615 & 3,607 & 3,542 & 10,615 \\
\hline
\end{tabular}


Table 11 Possible Mechanism: Ownership.

This table reports results on another possible mechanism through which management pay premium and employee pay premium affects firm innovation: firm ownership. SOE denotes state-owned enterprises and Non-SOE other firms. All denotes the whole sample. MPP denotes management pay premium, calculated as the average management pay $(A M P)$ in a firm relative to its industry-year median value; $E P P$ denotes employee pay premium, calculated as the average employee pay $(A E P)$ relative to its industry-year median value; IPP is industry pay gap, calculated as the ratio of the industry-year median of $A M P$ and industry-year median of AEP. Definitions of other variables are listed in Panel A of Table 1. T-statistics are displayed in parentheses. ***, *** and $*$ indicate significance at $1 \%, 5 \%$ and $10 \%$ respectively.

\begin{tabular}{|c|c|c|c|c|c|c|c|c|c|}
\hline \multirow[t]{3}{*}{ Variables } & \multicolumn{3}{|c|}{ LnPatent $_{t+1}$} & \multicolumn{3}{|c|}{ LnPatent $_{t+1}$} & \multicolumn{3}{|c|}{ LnPatent $23_{t+1}$} \\
\hline & Reg-1 & Reg-2 & $\operatorname{Reg}-3$ & $\operatorname{Reg}-4$ & Reg-5 & Reg-6 & Reg-7 & $\operatorname{Reg}-8$ & Reg-9 \\
\hline & $S O E$ & Non-SOE & All & SOE & Non-SOE & All & $S O E$ & Non-SOE & All \\
\hline$M P P$ & $\begin{array}{c}0.297 * * * \\
(6.812)\end{array}$ & $\begin{array}{c}0.296 * * * \\
(16.875)\end{array}$ & $\begin{array}{c}0.292 * * * \\
(10.244)\end{array}$ & $\begin{array}{c}0.278 * * * \\
(6.824)\end{array}$ & $\begin{array}{c}0.292 * * * \\
(18.720)\end{array}$ & $\begin{array}{c}0.218 * * * \\
(10.158)\end{array}$ & $\begin{array}{c}0.242 * * * \\
(4.977)\end{array}$ & $\begin{array}{c}0.202 * * * \\
(10.359)\end{array}$ & $\begin{array}{c}0.185 * * * \\
(7.446)\end{array}$ \\
\hline$E P P$ & $\begin{array}{c}-0.022 \\
(-1.349)\end{array}$ & $\begin{array}{c}-0.047 * * * \\
(-9.715)\end{array}$ & $\begin{array}{c}-0.022 * * * \\
(-4.097)\end{array}$ & $\begin{array}{c}0.004 \\
(0.272)\end{array}$ & $\begin{array}{c}-0.035^{* * *} \\
(-7.703)\end{array}$ & $\begin{array}{c}-0.012 * * * \\
(-3.224)\end{array}$ & $\begin{array}{c}-0.026 \\
(-1.315)\end{array}$ & $\begin{array}{c}-0.044 * * * \\
(-8.141)\end{array}$ & $\begin{array}{c}-0.018 * * * \\
(-4.366)\end{array}$ \\
\hline$I P G$ & $\begin{array}{c}0.053 \\
(0.630)\end{array}$ & $\begin{array}{c}0.229 * * * \\
(21.969)\end{array}$ & $\begin{array}{c}0.074 * * \\
(2.180)\end{array}$ & $\begin{array}{c}0.123 \\
(1.445)\end{array}$ & $\begin{array}{c}0.215 * * * \\
(22.735)\end{array}$ & $\begin{array}{l}0.044 * \\
(1.848)\end{array}$ & $\begin{array}{c}-0.023 \\
(-0.241)\end{array}$ & $\begin{array}{c}0.205 * * * \\
(17.746)\end{array}$ & $\begin{array}{c}0.036 \\
(1.209)\end{array}$ \\
\hline$M P P * S O E$ & & & $\begin{array}{c}-0.034 \\
(-0.996)\end{array}$ & & & $\begin{array}{c}-0.038 \\
(-1.475)\end{array}$ & & & $\begin{array}{c}0.019 \\
(0.624)\end{array}$ \\
\hline$E P P * S O E$ & & & $\begin{array}{c}0.018 * * * \\
(2.630)\end{array}$ & & & $\begin{array}{c}0.013 * * * \\
(2.671)\end{array}$ & & & $\begin{array}{c}0.015 * * \\
(2.571)\end{array}$ \\
\hline$I P G * S O E$ & & & $\begin{array}{l}-0.058 * \\
(-1.921)\end{array}$ & & & $\begin{array}{c}-0.024 \\
(-1.056)\end{array}$ & & & $\begin{array}{c}-0.043 \\
(-1.633)\end{array}$ \\
\hline Control Variables & YES & YES & YES & YES & YES & YES & YES & YES & YES \\
\hline Industry Effect & YES & YES & YES & YES & YES & YES & YES & YES & YES \\
\hline Year Effect & YES & YES & YES & YES & YES & YES & YES & YES & YES \\
\hline Constant & $\begin{array}{c}-17.326 * * * \\
(-16.080)\end{array}$ & $\begin{array}{c}-28.940 * * * \\
(-673.523)\end{array}$ & $\begin{array}{c}-0.683 * * * \\
(-4.696)\end{array}$ & $\begin{array}{c}-17.041 * * * \\
(-16.492)\end{array}$ & $\begin{array}{c}-25.161 * * * \\
(-642.116)\end{array}$ & $\begin{array}{c}-0.466 * * * \\
(-4.554)\end{array}$ & $\begin{array}{c}-18.414 * * * \\
(-15.350)\end{array}$ & $\begin{array}{c}-29.323 * * * \\
(-616.985)\end{array}$ & $\begin{array}{c}-0.470 * * * \\
(-3.730)\end{array}$ \\
\hline Obs & 7,468 & 3,322 & 10,790 & 7,468 & 3,322 & 10,790 & 7,468 & 3,322 & 10,790 \\
\hline
\end{tabular}

